\title{
Principles of Institutional-Evolutionary Political Economy - Converging Themes from the Schools of Heterodoxy
}

Phillip Anthony O'Hara

Over the past forty years there has been a considerable revival of heterodox political economy throughout the world. Heterodoxy has experienced a renewal in the form of several schools of thought. ${ }^{1}$ Institutionalists and evolutionary economists have proffered the significance of institutions and technological change. Post Keynesians have re-established the role of aggregate demand in a circular and cumulative framework. Neo-Marxists have sought to bring to the fore the importance of class analysis and economic surplus. Feminists have been active in fostering an integrative analysis of class, gender and ethnicity. Social economists have examined the role of justice, ethics and trust in institutions. Development and international political economists have recreated an interdisciplinary focus on the uneven forces operating in the global economy. In addition, ecological economists have linked the laws of thermodynamics with strong sustainability and the precautionary principle to create a durable edifice on the environment.

Several associations and journals have been established with a view to making heterodox political economy a viable scholarly undertaking. Institutionalists and evolutionary economists organized the Association for Evolutionary Economics in 1965 and began publishing the Journal of Economic Issues two years later. The Association for Institutionalist Thought has been active for twenty-five years now, and the European Association for Evolutionary Political Economy began operating in 1989. Recently the Journal of Institutional Economics commenced publication; while the International Schumpeter Society began their affiliation with the Journal of Evolutionary Economics in the early 1990s. Post Keynesians commenced the publication of the Cambridge Journal of Economics and the Journal of Post Keynesian Economics in the late 1970s. Marxists and radicals formed the Union for Radical Political Economists

The author is Professor of Global Political Economy and Governance and Director of the Global Political Economy Research Unit, Curtin University, Perth, Australia. He was helped by the provision of comments by the three anonymous referees; the editor and Vicki Taggart; John Davis; and Ron Stanfield. Email: philohara@runbox.com 
in 1968, and begun publishing the Review of Radical Political Economics a year later. Several other radical journals emerged, such as Capital and Class, Studies in Political Economy, the Journal of Australian Political Economy, and Rethinking Marxism. The International Association for Feminist Economics was instituted in 1992, three years before their journal, Feminist Economics, was created. Social economists changed the direction of the Review of Social Economy in the early 1970s under the impact of the 1960s reform movements, and established the International Journal of Social Economics in 1972 along with the Journal of Socio-Economics in the mid-1990s. Those with a penchant for the environment created the International Society for Ecological Economics in 1989, along with Ecological Economics; while Capitalism, Nature and Socialism has been published quarterly since 1990. Several other journals also emerged with a political economy agenda, such as the Review of Political Economy, New Political Economy, Economy and Society, plus the Review of International Political Economy, World Development and the Journal of Human Development. ${ }^{2}$

In addition, heterodox political economy has been supported by an array of publishers, conferences and academic institutions. Most academic and University publishing houses have a section in their catalogue on political economy. Some have an explicit mandate or interest in heterodox themes, such as Monthly Review Press, Zed Press, and Pluto Press. Commercial publishers that have been especially supportive include Edward Elgar, M.E. Sharpe, Greenwood, Transaction, Palgrave/Macmillan, Routledge and Cambridge. Conferences have blossomed, the main ones being associated with the Allied Social Science Associations, the Association for Institutional Thought, Post Keynesian Workshops, World Congress of Social Economics, the Association for Heterodox Economics, the summer conference of the Union for Radical Political Economics (URPE), the annual European Association for Evolutionary Economics meetings, and the Triennial International Confederation of Associations for Pluralism in Economics (ICAPE) Conference. Numerous academic institutions have "supported" political economy programs. They are so numerous as to defy simple numeration, but include Cambridge University, Colorado State University - Fort Collins, the New School for Social Research, Santa Fe Institute, Sussex University, Sydney University, University of California - Riverside, University of Leeds, University of Massachusetts - Amherst, University of Missouri Kansas City, University of Notre Dame, University of Sienna, and the University of Utah. $^{3}$

With all this activity, one would expect several clear statements of the main concerns of political economy to have emerged over the past couple of decades. One would also expect the emergence of a fairly clear set of theoretical propositions, culminating in the evolution of certain principles, to provide a setting for empirical analysis and future development. Indeed, the individual schools of thought have produced something approaching this; and several scholars have sought to provide some unifying threads for an overall political economy perspective to emerge, such as Marc Lavoie (1992), Jason Potts (2000), Charles Clark (2001), and Phillip O'Hara (2001). ${ }^{4}$ No one to date, however, has produced or come close to producing the magnum opus - equivalent to Veblen's Theory of the Leisure Class ([1899] 1965), 
Keynes's The General Theory of Employment, Interest and Money (1936), Marx's Capital ([1867] 1976; [1885] 1978; [1894] 1981), or Schumpeter's Theory of Economic Development ([1911] 1938) - to impact the profession as a whole and set a standard for teaching, research and policy-making.

Some may maintain no such magnum opus is feasible in a decentered, postmodern world; while others may posit that the great masters of political economy (Veblen, Keynes, Marx, Schumpeter) have already produced them. Some skeptics suggest that major advances have already been incorporated into a healthier, nonWalrasian, non-neoclassical economics (see Bowles 2004); while other skeptics may suggest that there is little uniting these disparate schools of heterodox thought except perhaps a disdain for (especially Walrasian) orthodoxy, and perhaps that even the individual schools of heterodoxy have trouble promoting conceptual clarity. ${ }^{5}$ The argument of this paper is what may be called a "minimalist argument" for convergence, namely, that many sub-schools of institutional-evolutionary political economy, but not all, have been converging in the institutional-evolutionary direction, and that there is much to indicate the evolution of a relatively coherent set of institutional-evolutionary principles in motion to help comprehend modern society and governance. The objective of this paper is to present a set of such principles, which are becoming coherent and evolving over time.

There is a clear thread of institutional-evolutionary conceptualization running through many writers and sub-schools within institutional evolutionary political economy (IEPE). The history of the linkages between these sub-schools goes back to the classical economists, especially Adam Smith, Thomas Malthus, and Karl Marx; and the work of the historical school and institutionalists such as Thorstein Veblen, Gardiner Means, Wesley Mitchell, Gunnar Myrdal and Karl Polanyi. It also encompasses the Cambridge and latterly post Keynesian work of Nicholas Kaldor, Michael Kalecki, Joseph Steindl, and J.K. Galbraith; and the institutional trend in neo-Marxian economics that weaved a threat from Rudolf Hilferding through to Paul Sweezy and Samir Amin. Further linkages include the radical-Schumpeterian trend that enriched the study of long waves, institutions-technology interface and industrial metamorphosis; successive waves of feminist thought that impinged on social and economic thought; and the revival of political economy since the 1960s. This revival, of special relevance to this paper, saw the emergence of a degree of convergence that emphasized realism, holism, circular and/or cumulative causation, institutions, and the role of values and social factors in economic life. Institutional-evolutionary themes thus provided a critical basis for this recent convergence.

Figure 1, provides a summary of the main authors and concepts discussed in this paper, showing there to be seven (interacting) sub-schools of IEPE that have relatively close network densities vis-à-vis convergence. ${ }^{6}$ Through these seven subschools, institutional-evolutionary political economy led the trend away from mere formal theory to a realistic analysis of the institutional evolution of capitalism through historical time. The first is the sub-group of "Major Heterodox Convergers" who have persistently written about the theme of linkage and convergence around institutionalevolutionary concepts. They include, among others, Charles Clark, Marc Lavoie, Tony 


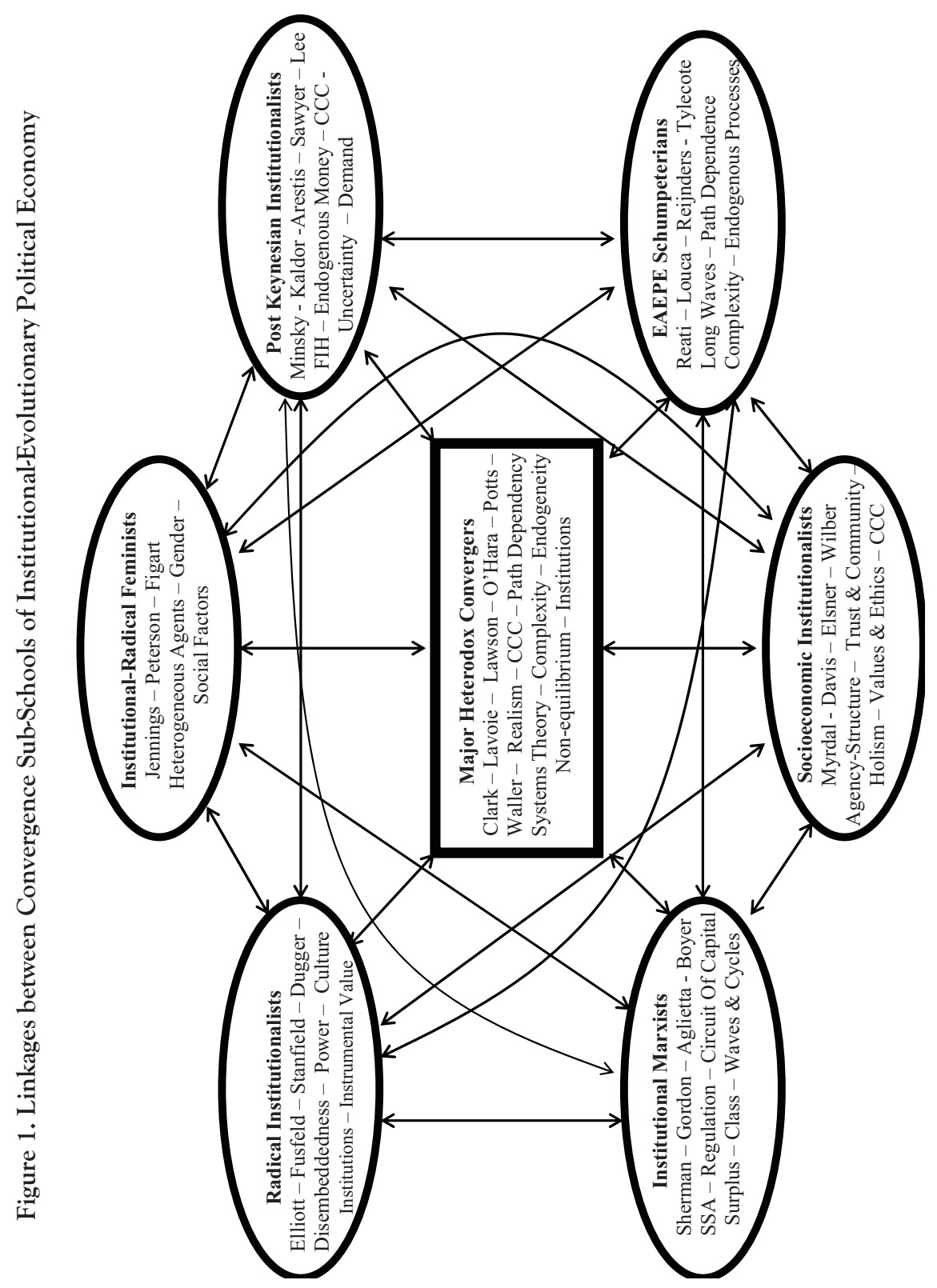


Lawson, Phil O'Hara, Jason Potts, and Bill Waller, and provide the main arguments for a high degree of convergence. The second are the "Radical Institutionalists" within original institutionalism, including John Elliott, Daniel Fusfeld, Ron Stanfield, Bill Dugger, Rick Tilman, and their followers. The radicals have been especially notable in promoting linkages between certain heterodox schools, including instrumentalists such as Marc Tool and Dale Bush and many of the other six sub-groups.

The third group is the "Institutional Marxists," or radical political economists, who have persistently argued for an institutional-evolutionary trend in political economy. They include scholars such as Howard Sherman, David Gordon, Michel Aglietta, Robert Boyer and their followers. Howard Sherman and David Gordon have especially linked their trend to other schools of heterodoxy, and the radical institutionalists have been singing the praises of this group for decades. The fourth group, with a strong institutional-evolutionary perspective, is the "Post Keynesian Institutionalists," including such writers as Hyman Minsky, Nicholas Kaldor, Philip Arestis, Malcolm Sawyer, Fred Lee, and their followers. Minsky, Kaldor and Arestis consider(ed) themselves both institutionalists and post Keynesians - as do many other scholars such as John Harvey, Michael Radzicki, and Randall Wray while Sawyer, in addition, sees himself as having additional links with Kaleckians and Marxists. The fifth group is the "Institutional-Radical Feminists," a combination of institutional feminists such as Ann Jennings, Janice Peterson and Deb Figart, plus a number who came out of the feminist-Marxist movement of the 1960s and 1970s. These scholars have consistently argued for an institutional-evolutionary framework of analysis.

The sixth grouping is the "Socioeconomic Institutionalists," such as Gunnar Myrdal, John Davis, Wolfram Elsner, Charles Wilber and their supporters, who promote institutional and evolutionary themes associated with structure-agency, a holistic methodology, trust-networks, circular and cumulative causation (CCC), and coordination problems. Davis, Elsner and Wilber came out of the broad heterodox movement of the 1960s and 1970s with a strong commitment to convergence with some other heterodox scholars and organizations. Lastly, there are the "EAEPE Schumpeterian" institutional-evolutionary scholars, such as Angelo Reati, Francisco Louca, Jan Reijnders and Andrew Tylecote, who have consistently examined the relationship between technology and institutions through long waves and evolutionary processes. All four have strong links with the European Association for Evolutionary Political Economy (EAEPE), and are quite close to the radical and progressive institutionalists, institutional Marxists and post Keynesian institutionalists in their theoretical and policy perspectives. In this, they are more heterodox than standard Schumpeterians.

We thus delimit the focus to the emerging convergence theme associated with the above seven sub-groups linked to specific principles of institutionalevolutionary inquiry. Special reference is given to what we call "substantive principles" associated with the historically specific workings and evolution of institutions. This is contrasted with "methodological principles" and the history of such principles, which has already been discussed in some detail elsewhere (O'Hara 1993; 2000); although 
this paper does touch on them to show linkages between methodology and "substantive" institutional-evolutionary questions. Such delimited inquiry is necessary for the contents of a relatively short journal article.

\title{
General Principles of Institutional-Evolutionary Political Economy
}

It is necessary to start with a general view of institutional-evolutionary political economy (IEPE) vis-à-vis our seven sub-schools, including a working definition to start the analysis. We could say that IEPE is "what these seven sub-groups of political economists do." I prefer to be more specific. Hence, to start the story let us define it thus:

\begin{abstract}
Institutional-evolutionary political economy is a realistic, interdisciplinary study of the dynamic structure, evolution and transformation of human action within socioeconomic systems, paying particular attention to the reproduction, functions, contradictions, and unstable dynamics of the institutions of production, distribution, and exchange of material and immaterial resources set within a social and ecological environment through historical time.
\end{abstract}

Central to this view of IEPE is a study that is realistic, interdisciplinary, humancentered, and systems-oriented; as well as one that links human action with structure, reproduction with contradiction, material with immaterial, and social with political in addition to ecological. IEPE seeks to develop an analysis that is realistic in the sense of "keeping close to the ground," being concerned with the institutions of the system, and incorporating a bounded form of rationality that recognizes the limits of the human mind and the asymmetric distribution of knowledge as well as economic agents' relative ignorance of the future.

\section{Realism and Complexity}

The vast majority of IEPEs argue that the study seeks to be "realistic," in the sense of trying to comprehend or understand the underlying processes at work in the spheres of production, distribution, exchange and socioeconomic reproduction (Lawson 1994). It seeks to eschew abstractions from the economic system to develop a pragmatic framework for analyzing these processes through real time. The system includes real human agents and undergoes phases of evolution. Critical to this realistic framework is an analysis that seeks to endogenize the critical factors at work, in particular to endogenize preferences, technology, knowledge and institutions. Indeed, rather than starting with ceteris paribus assumptions where medium and long-term processes are not affecting the system, IEPE is primarily concerned with the formation and change of these preferences, knowledge, technologies and institutions through historical time. 
This critical form of realism is based on holism, causal processes, and retroduction In being holistic, it utilizes an open-systems methodology, pattern models and participatory observation (Gruchy [1947] 1967; Kapp 1968; Wilber and Harrison 1978). Open systems recognize the need to endogenize as many variables as possible, where the sub-systems are linked together, and multi-causal processes are at work. Pattern models center on the relationships impinging on the system through interdependencies and reciprocal exchanges, including mental models developed by agents to make sense of their world. Participatory observation can enhance the degree of realism by the investigator operating within the institutions under investigation. In doing so they can understand, for instance, how corporations price commodities; how capital-labor relations evolve through time; how communities interact and communicate; how consumers create models of how to choose commodities and products; and how successful states might be in providing public goods.

In trying to comprehend the deeper layers of social reality, case studies, fieldwork, interviews, newspapers, theoretical sampling, and seeking diverse sources of data can enhance understanding. Grounded theory has been demonstrated to help in comprehending the causal processes involved (Finch 2002; Lee 2002a). Going beyond specific cases is possible through comparative analysis, the iterative process, and recognizing the complexity of the interactions and evolution. Retroduction grounds the inquiry to promote generality through the movement from observation to structural causes. Hence, realism seeks to go beyond (or explain) mere surface phenomena through an analysis of tendencies, complexities and alternative dynamics of the institutional fabric (Downward, Finch, and Ramsay 2002).

Every age has its own theoretical systems or paradigms with which to embed their principal ideas. In previous times, it was Newtonian comparative statics, or Darwinian evolution, dialectics, or historical determinism, depending on the theorist. In the current epoch, much is being written about dialectics, and historical and evolutionary analysis as viable frameworks. However, a more contemporary framework may enable the best of dialectics, history, and evolution to be embedded in the analysis. Complexity theory is seen by many as a potentially viable general theory with which to link the dominant aspects of the analysis in discourse. Indeed, it seems to be the case that complexity may be a general framework within which most IEPE perspectives can be embedded.

Complexity theory fuses some critical elements, such as evolutionary propositions, endogenous processes, self-reproduction, emergent properties and holistic relationships. This is ideally suited to political economy since it posits no general equilibrium, a constant flux of variables interacting through historical time, and a transformational reality of change and uncertainty. Of particular interest is the tendency for positive feedback changes in values to have a significant and non-linear impact on the system as a whole, which brings to mind the circular and cumulative causation analyses of Gunnar Myrdal and Nicholas Kaldor. Because it is a holistic study, it is likely that contradictions and paradoxes emerge in the organization of institutions and technologies. The system endogenously evolves due to the inherent life of the complex processes involved in real world dynamics. Irreversibility is 
patterned into the dynamics because the process of change impacts institutions and technologies that are subject to path dependence and metamorphosis. This is ideally suited to an analysis of capitalism that is imbued with uncertainty, due to investment being dependent on future expectations upon which knowledge is small or nonexistent (see Colander 2000; Potts 2000; Ofori-Dankwa and Julian 2001; Barnes, Gartland, and Stack 2004).

\section{Agency and Structure}

IEPE has been resolving an old and complex problem that has proved to be a thorny issue throughout its history. This is the problem of individuals and structures. Traditionally, political economists have ignored individuals in favor of structures such as economic systems, institutions, cultures, ideologies, classes, gender, race, and so forth. It is now recognized how critical it is to link agency with structure. Both individuals and structures must be integrated into the analysis. Samuel Bowles, John Davis, Geoff Hodgson, Tony Lawson, Richard Wolff, Stephen Resnick and many others have recently brought this issue to the fore. This issue has built bridges between institutional-evolutionary perspectives. Figure 2 illustrates some of the important factors in this new agency-structure analysis. ${ }^{8}$

The principle of agency and structure demonstrates that individuals and structures interact through time in the determination of socioeconomic processes. Individuals have certain preferences, resources, sentiment and trust that impact on their quality of life and contribution to society. Structures also impact individuals, be they families, classes, gender, race, institutions, networks and/or the gene pool. The principal task for IEPE is to situate theory and practice in a framework of dual interdependency between agency and structure, within which the "social individual" operates. This task is made easier since individual preferences, resources, sentiment and trust need to be understood as changing and continually being reproduced

Figure 2. Agency and Structure

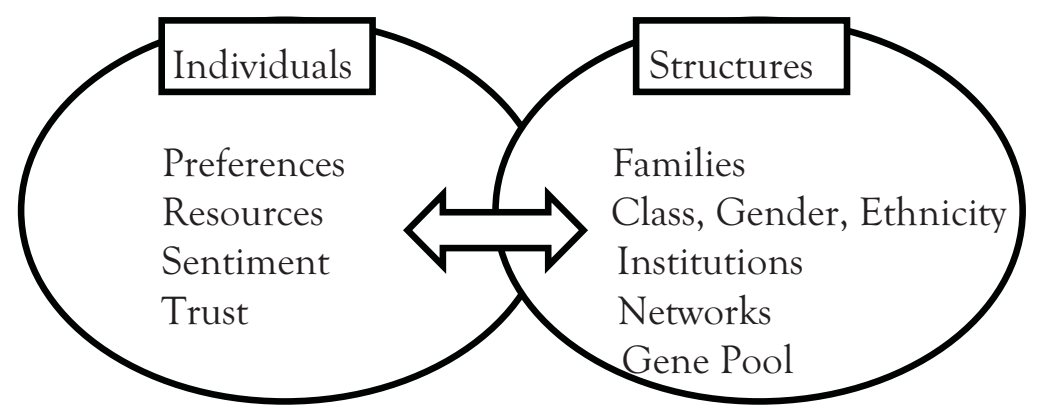


through time (Rodrigues 2004). It is also important to differentiate between needs and wants and to situate needs within the context of various sub-principles such as bounded rationality, satiability, growth and interdependence (Lavoie 2004).

IEPE knowledge is anti-foundationalist in the sense of being constantly in motion, conditional and provisional, subject to change, and contextualized into the community as a social science. It is not subject to an overriding general theory that is abstracted from the prevailing historical and institutional environment. Rather, it is situated within the structures, processes and tendencies of economic systems and human behavior that evolves in the community. It certainly has some philosophical preconceptions, which mould the nature of the questions, issues, and perspectives that arise, but it also has a body of substantive knowledge that is subject to empirical inquiry, is relatively durable, yet subject to change on the basis of further evidence.

Central to the preconceptions of IEPE is a critique of dualisms such as objectivesubjective, mind-body, social-individual, deduction-induction, and materialisticidealistic. It cannot be value free because the very questions it raises, the assumptions it utilizes, the areas it scrutinizes, the methodology it embraces, and the political and social perspectives it seeks to encourage are imbued with passion and humanity. These are all conditioned by valuations, ideologies and the prevailing traditions of the community. Rather than utilizing purely empirical or theoretical traditions, IEPE utilizes abduction or retroduction, in which social structures, tendencies and processes are examined with a view to explaining their nature and evolution. IEPE seeks to transcend (or explain) mere surface phenomena such as historical events and popular culture through a critical analysis of the deeper layers of social reality.

\section{Historical Specificity, Social Capital and Heterogeneous Agents}

\section{Historical Specificity}

If institutional-evolutionary political economy eschews general principles that are transhistorical, invariant to time, and foundational then what sort of principles can it adopt? It can utilize principles that are subject to change, that are linked to the historical and cultural fabric of the community, and that have imbedded in them a relational and open system of linkages. As Karl Polanyi (1968) said, such principles are "substantive" in the sense of being part of and linking to the institutional and temporal processes of the economy. We thus come to the principle of historical specificity and evolution, that IEPE is a substantive study, and that it must be imbedded in the historical and institutional structure of social economies through time.

This, of course, raises the issue of economic systems and their evolution. IEPE necessarily recognizes the existence of different forms of socioeconomic formations, and their metamorphosis and transformation through long periods. In the past, there were different forms of organization, such as primitive communistic systems, slavery, feudalism, plus mercantile as well as manufacturing forms of capitalism. Today, most are capitalist, although there are different forms of capitalism. For instance, there are the "liberal democracies" such as the United States, the "social 
democratic" types like Sweden, the "corporatist" varieties such as Japan, the "transitional" varieties in the former "communist" countries of Russia and the Ukraine, the "state capitalist" dictatorships of China and Vietnam, and the "emerging" capitalist nations of Asia such as Malaysia, Indonesia and Thailand.

Capitalist economies undergo metamorphosis through time, such as Mercantilism - in the early years when trading and the creation of the world market was in its infancy. Thereafter, many capitalist countries went through the stage of manufacture, with the development of the cotton industry, textiles and clothing. This was followed by the industrial revolution, when iron and steel led the way to the development of the processing industries. Imperialism and finance capital was strong in the late 1800 s and early 1990s, which was also characterized through the early-mid 1900s by the development of consolidation, mergers and oligopoly structure. The period within and between the two world wars was characterized by much conflict, economic malaise and beggar-thy-neighbor policies. After WWII the advent of Fordism and the Keynesian welfare state led to twenty or thirty years of relatively strong growth for the advanced nations. During the 1980s-2000s, neoliberal globalization emerged through reducing the power of labor relative to capital; deregulating financial, labor and foreign exchange markets; and the renewed dominance of brute individualism and business interests.

Meanwhile, much of sub-Saharan Africa emerged from imperial exploitation with artificial boundaries, inadequate infrastructure, fragmented institutions and regular bouts of drought, flood, and war; plus more recently the seemingly permanent ghost of AIDS. Latin American nations also failed to emerge as leading players in production chains, as they slavishly undertook IMF (International Monetary Fund) World Bank structural adjustment programs in the 1980s and 1990s, followed by financial and economic crises in Argentina, Brazil and Uruguay, and the recently elected socialist governments. Terms of trade problems, inadequate social capital and corruption plague much of the periphery. East Asian nations have been drawing away from the semi-periphery toward the center as they develop effective industrial policy, production-distribution regimes and commodity chains. China is currently leading the field of capitalist development through market reforms, the movement of labor to urban areas and partnerships with transnational corporations (O'Hara 2006c). Meanwhile, Eastern European former "state capitalist" economies such as the Ukraine and Russia are still trying to re-establish 1990 levels of gross domestic product (GDP), while their Central European neighbors are generally moving ahead through membership of the European Union. From this irregular global pattern, political economists have been developing North-South models of divergence, institutional theories of growth and development, and realistic approaches to social reproduction (see Dutt 2003). 


\section{Circuit of Social Capital}

IEPE is detailing the reproduction processes involved in the production, distribution and exchange of economic surplus. The principle of the systemic circuit of social capital (SCSC), especially the circuit of money capital, has been used by IEPE scholars, particularly institutional Marxists, radical institutionalists and post Keynesian institutionalists. Figure 3 extends the circuit to social, ecological and governance spheres, in recognition of recent advances in these fields (O'Hara 2004a, 57).

The SCSC illustrates, firstly, how the reproduction of social and material relations of production and circulation are embedded in a system of "cultural relations," which constitutes the way of life of the community, including the differential norms, mores and practices of the people. Culture also includes the relations of status and ceremony, as well as class, ethnicity and gender, which have regional variation and modes of uneven development. Secondly, the reproduction of the SCSC is embedded in a spatial and ecological environment; as well as governance relations that embody the rules, laws and regulations channeling and directing the practices of individuals, corporations and groups. Thirdly, the SCSC is embedded in a myriad of relations of "trust and association" through global, regional, national, and local processes.

Set within this broad institutional and social environment, the SCSC can be seen to "commence" with a system of "familial reproduction" (FR), which constitutes the roles, practices and forms of care that are embedded in households; between parents, children and others. Familial reproduction potentially enables the emergence of a stable environment for people to structure their social practices, and for personality and emotions to evolve. Closely linked to the family are relations, friends

Figure 3. Systemic Circuit of Social Capital

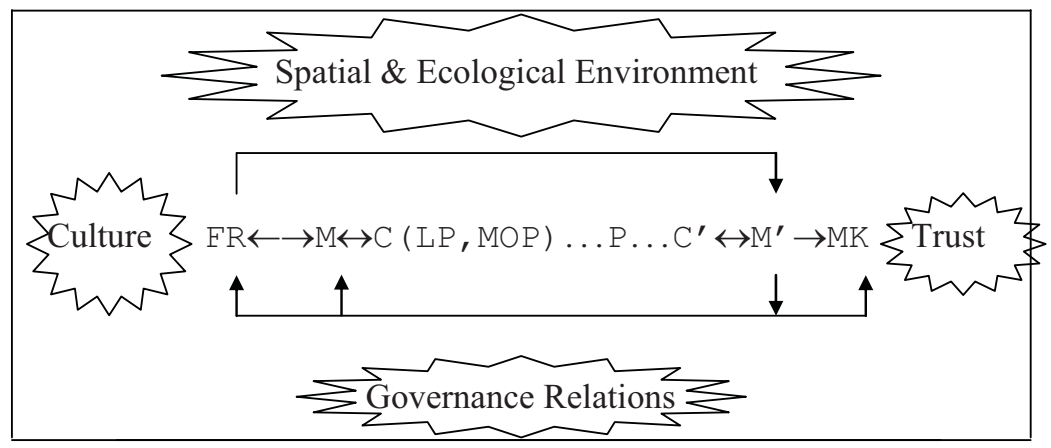

$\left.\sum_{3}^{5}\right\}=$ Indicates a multiple source of interaction and influence within the SCSC 
and community linkages. The trust and association developed in the family and community may help the market for intermediate goods and services through enhancing the quality of labor power and conditioning consumption patterns and spending decisions.

The second dynamic structure of the inner SCSC includes decisions to exchange money (M) for commodities (C) such as labor power (LP) and means of production (MOP) in the market for intermediate goods and services. This involves agreements and relationships between capital and labor (or their representatives) in the distributive struggle over shares of national or international income. It also involves structures of competition and pricing in the market for capital goods and material inputs; including machinery, factories, oil, gas and other raw materials. Bottlenecks at this phase of the circuit can have a negative impact on the reproduction process as a whole. Family relations, trust, association and culture can also affect these practices.

The third phase of the inner SCSC involves the direct production process (... P...), including the valorization of capital, which includes the production of surplus product (C'). This involves all major relations and processes associated with the ability of capital to subordinate labor and extract surplus product through an array of technological, organizational, supervisory and governance structures. However, before the surplus product can become effective it requires a fourth phase, the pricing and realization process through market demand $\left(\mathrm{M}^{\prime}\right)$. Without the ability of capitalism to create sufficient demand - through a combination of consumption, investment, government spending and/or net exports - the surplus value remains only potential rather than actual. Familial relations and trust are important to this process. Lastly, for the SCSC to be fully reproducible requires that corporate finance (M'), or endogenous money and credit through the financial system (MK), be (re)invested into the market for intermediate goods and services (M) as well as through the system of familial reproduction (FR). And so on ad infinitum as the circuit becomes reproduced through varying turnovers of capital.

The factors responsible for the generation of the surplus are potentially multifarious, linking various system-factors, coordinating processes, demand-supply variables, trust, culture, and individual contributions. However, there is also a role for exploitation as the vested interests and dominant classes exploit public goods, organizations, and laboring classes for their own benefit at the expense of the majority.

\section{Heterogeneous Agents}

Crucial to this circuit is the principle of heterogeneous agents, which states that there are multiple roles played by agents in the circuit, due to the asymmetric distribution of power and resources. Individual preferences and resources are affected by their institutional, cultural and biological environment, including genetic makeup and family background, occupational and income status, ethnic and class positions, as well as gender disposition. These multiple roles are also affected by corporate, media and 
party-political institutions. Individuals do not exist as an island, but interact and are affected by other individuals, friends, family, groups, organizations and systems of belief and valuation. In this system of influences, class, ethnicity, gender and species are critical (see O’Hara 2006a).

The intergenerational transfer of resources and preferences from parents, family, and friends is an important determinant of the life possibilities open to people. Class tends to follow family background, as the resources offered to members of families, their friends and relations fundamentally influence the quality of parental guidance, school attendance, and occupation. The ability of parents to influence the intergenerational transfer of resources to their offspring is a critical determinant of the material and cultural advantages they will bring to bear on the future. Typically, class relations inhibit the realization of potential for a large percentage of the population as they have limitations on formal education, travel, trust and networks. On the other hand, being a member of the upper class(es) provides access to a culture of privileges, including status, comfort, and substantial resources throughout life. The existence of multiple class positions makes the analysis more complex and realistic (Resnick and Wolff 2005), since heterogeneous roles pervade individual social behavior.

Ethnicity is also important. Being brought up in a minority group tends to inhibit the ability of people to realize their potential in areas such as occupation, income, and networks. Minorities tend to have a higher than average incidence of crime and incarceration, lower educational opportunities, plus smaller income, and wealth. In general, their life chances are inhibited due to factors beyond their control. For instance, being part of an indigenous population is a handicap since usually not only one's parents, but also other relatives, friends, and neighbors have a reduced ability to participate actively in the economic, political, and social affairs of the region, nation, and world. When a neighbor or relative becomes more successful, they usually move to a "better" suburb or area, thus reducing the extent to which they function as a role model for others. The negative affects of membership of lower socioeconomic ethnic groups on health and well-being is well known and documented extensively in the literature (e.g., see Drentea and Goldner 2006).

Gender also impinges on the unequal distribution of resources. Historically, the gender one is born with has influenced the power one has in different spheres of socioeconomic life. Throughout much of history - still in many nations - women have looked after the family in the private sphere while men worked in the public sphere of life. This asymmetric distribution of social power usually gave men the capability of determining the nature of the institutions of production, distribution and exchange, as well as the shape of the spheres of politics and the world economy. Women may have had some power in the household, but little control over social resources, economic and political power, and the shape of the world. In the West, especially, women have been questioning this patriarchal dominance, and some redistribution of income, wealth and power has occurred over the past sixty years. Substantial power differentials still exist, even in the Western world, that continue to impinge on gender access to resources and quality of life. In heterosexual 
relationships, for instance, women tend to perform a double day; they work for wages and then do most of the household labor, which negatively affects their level of wellbeing (MacDonald, Phipps and Lethbridge 2005).

Species is another important "difference" that impacts the political economy. Human beings, as the dominant species on Earth, are able to set the tone for (hegemonic) debate, providing the myths and legends that legitimize their power in the ecological environment. The fact is that Earth is under the sway of a species that has colonized most habitats and destroyed a large proportion of the species. Biodiversity has been declining, especially over the past two hundred years when human beings created a system of industrial and commercial power that severely diminished the ability of other species to maintain their stock of genes in the pool of characteristics that determines their ability to reproduce themselves through long historical time. This is a contradictory process, however, since destroying other species and habitats will eventually adversely affect the standard of living and quality of life of human beings themselves. This is especially pronounced through pollution, global warming, and declining interaction with other species (see Brennan 2004).

The combined impacts of the institutional and cultural fabric underlying class, ethnicity, gender and species are the major processes underlying the social pattern of power and inequality in the global, regional, national and local political economies. $^{9}$ Many recent works in IEPE from our sub-schools - especially radical institutionalists, Marxian institutionalists, institutional-radical feminists, and socioeconomic institutionalists - provide a foundation for linking multiple roles in heterogeneous agent discourse.

\section{Creative Destruction, Money and Finance as Endogenous Processes}

With the introduction of dynamics more specifically into the framework, it is necessary to deepen the role of the global political economy. Capitalism is by its very nature a global system, with a revolutionary modus operandi, and the process of creative destruction. The very nature of capital creates a movement for the expansion of markets, the introduction of new methods and products, and the constant interruption of established lines of business. Competition and innovation form a dialectic that enables capital to constantly grow and develop in more nations and geographical areas than ever before. New combinations can take five main forms, including product innovation, process innovation, new sources of raw materials, the opening up of a new market, and changes in the organization of industry (Schumpeter [1911] 1938, 63-66). These can be activated by single entrepreneurs, partnerships, large corporations or production networks. Degrees of monopoly power through institutionalizing innovation create economic rents or economic surplus that business is perpetually seeking. If there are low barriers to entry then the process of competition is able to reduce the super-profits that spur entrepreneurial activity. 


\section{Dialectic of Innovation and Competition}

To comprehend the forward motion of capitalism requires the principle of the dialectic of innovation and competition linked to dynamic motion and metamorphosis. Capitalism requires both an active entrepreneurial function and a reactive competitive motion for its inner logic. Continual innovation-competition enables this logic to flow through to growth and accumulation. A reduction in this dual innovationcompetition motion leads to reproduction problems. If innovation is not strong enough accumulation falters due to declining expected monopoly rents, while if competition is too strong the monopoly surplus accrues to firms for too short a time, again leading to problems of accumulation. Thus, there are narrow parameters that enable capital to operate crisis free.

The innovation-competition dialectic that forces capital to open up new areas for these new products and processes is a process of creative destruction set in an environment of instability and change. Uncertainty is the normal rule of capital as the development of new combinations is endogenously set in motion by the need for profits at the global level. The search for such profits upsets established lines of business, destroys traditional lifestyles, leads people to separate from family and friends, reduces biospheric diversity as the land is cultivated and new firms are organized, and periodically leads to unemployment as old skills become obsolete.

The principle of uncertainty really comes into its own, however, when the innovation-competition dialectic is set within the context of a global system dependent not only upon internal sources of funds but also credit finance. The process of generating innovation and competition only really takes on a capitalist dynamic when credit is introduced into the picture (Farrari-Filho and Conceição 2005). The business environment is characterized by radical uncertainty and ignorance because the future is unknown and unknowable. Yet future profit in the form of successive streams of prospective yield minus supply price (suitably discounted) forms the basis of the spirit of capitalism. The introduction of credit magnifies the uncertainty because the search for profit in the future in an environment of ignorance based on accruals of debt lead to greater potential profit variance (Keynes 1936).

This leads us to the principle of endogenous money and credit where finance is created out of the demand for money, characteristic especially of the upper phases of the business cycle (Arestis 1997). During the upswing in the cycle, economic activity expands, along with the need for outside financing. Firms and banks engage in greater levels of borrowing and lending, respectively, and if there are severe limits to such finance this usually leads to financial "innovation" to create instruments and funding opportunities to satisfy the demand. Post Keynesian institutionalists, institutional Marxists and heterodox convergers, in particular, have undertaken much research on the two main sources of endogenous finance, accommodative and innovative/structural. While the historical weight of argument seems to support business-innovative sources, recent monetary policy interest rate targets lend some credence to accommodative finance; although it has to be said that when interest rates are raised this reduces the degree of accommodation (Rochon and Vernengo 2001). 
Financial Instability Hypothesis

In this context, Hyman Minsky's (1982) financial instability hypothesis (FIH) has become a major source of convergence, and Minsky himself saw his analysis as linking many schools. Post Keynesian institutionalists and institutional Marxists have been especially active exploring and improving the analysis of financial instability and crises The FIH links many themes in IEPE, including endogenous finance, the conflict between finance and industry, radical uncertainty, and the trend to financial crises during long wave downswings.

In Figure 4, below, we utilize a system dynamics style stock-flow analysis to explain the FIH, following the original systems work of Jay Forrester (1956 2003), plus the IEPE-systems work of Glen Atkinson (2004) and Michael Radzicki (2006) who argue system dynamics enhances an understanding of institutional-evolutionary processes.

Figure 4: FIH System Dynamics Stock-Flow Analysis

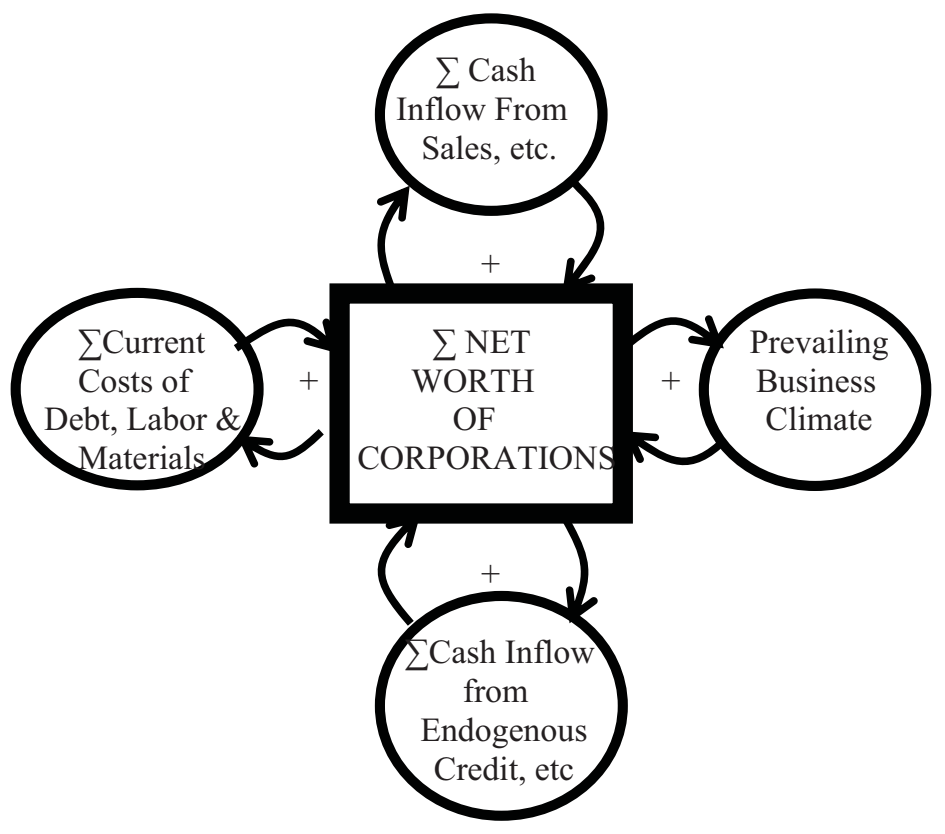


The rectangle is the principal stock, namely, the total net worth of corporations in a national economy, constituting the difference between total assets and liabilities. The circular boxes are the main flows. The top circular flow, total cash inflow from sales, etc., is a positive feedback loop enhancing expectations, profit and investment. The bottom circular flow, cash inflow from endogenous credit, etc., is both a positive and negative feedback process, depending on the nature of the business climate. In general, the left side circular flow, current costs of debt, labor, materials, and so on, is a negative feedback process, since such debt tends to moderate profit, investment and business climate. The right side circular flow, the prevailing business climate, generates a flow of expectations from the institutional environment that can generate positive or negative feedback depending on circumstances. The main determinants of net worth are the expectations emerging from the current business climate, especially those determining the valuation of assets and liabilities linked to current levels of uncertainty. When recognized uncertainty is low and expectations are buoyant, this heightens the value of assets and reduces the calculable valuation of recognized risk; the opposite occurs when uncertainty is high.

A Wall Street perspective is important since cash flow and net worth are linked to financial speculation, investment and business cycles. In a typical endogenous cycle upswing, expectations tend to become exaggerated as recovery moves into medium-upswing. In this increasingly euphoric environment, cash flow (income flows, YY, minus contractual commitments, CC) becomes positive by a margin of safety ( $(\mathfrak{W})$ ), while capitalized $(\mathrm{K})$ net income (capitalized YY minus capitalized CC, a balance sheet item approximating net worth) is also positive by a margin of safety $(m)$.

$$
\begin{aligned}
Y Y=m C C & (\text { where } m>1 \& Y Y>C C) \quad(1 a) \\
K(Y Y)=m K(C C) & (\text { where } m>1 \& K(Y Y)>K(C C)) \quad(2 a)
\end{aligned}
$$

This FIH situation of "hedge finance" is apparently safe, but actually unwittingly sets the scene for financial fragility. During periods of "good" business, firms become optimistic, and this optimism leads to greater investment, which may also encourage consumption spending. Firms expand, domestically and globally, setting the scene for a typical boom in the cycle. Projects are put into action - both innovative and general - leading to greater multiplier and accelerator effects that enhance the upward movement of the cycle. Business tends to extrapolate these good times into the future, through positive feedback, leading to high investment that can be upset by many endogenous, negative feedback, forces of the cycle. As the prevailing business climate becomes more buoyant, speculative asset valuation is enhanced as it deviates from fundamentals (even as the latter may be growing). This endogenously leads to greater credit availability from financial institutions and other institutions (e.g, trade credit), which expand real and speculative excesses.

Around the mid-point of the boom in the business cycle upswing, some firms move into problematic cash flow positions as they expand credit when interest 
rates are rising. There also may be cost and demand anomalies starting to impact. This leads to the situation where cash flow for many firms becomes negative, while in the long-run they are seemingly sound. The buoyancy leads to growth rates of expected income to rise further than actual income - generating greater credit - as firms extrapolate growth into the future:

$$
\begin{aligned}
Y Y=m C C & (\text { where } m<1 \& Y Y<C C)(1 b) \\
K(Y Y)=m K(C C) & (\text { where } m>1 \& K(Y Y)>K(C C)) \quad(2 b)
\end{aligned}
$$

This financial position, what Minsky calls "speculative finance," is not too problematic as business considers it a temporary anomaly soon to be rectified as investments lead to better cash flow positions. They are still investing based on a good investment and speculative climate. However, the endogenous forces of the boom tend to generate further anomalous, negative feedback, forces that reduce cash flow for many firms while eventually leading to negative capitalized positions in the balance sheet as net worth deteriorates. An important process is described by Kalecki's principle of increasing risk, where business cycle upswings endogenously lead to higher risk. As the boom develops to higher levels investment expands greatly, and risk rises in proportion to the increasing investment for sole traders, partnerships, and corporations. This is the case regardless of whether investment is financed through borrowing, bonds or shares. The higher the level of investment, the greater the risk if the projects fail. If investment is financed by borrowing, and prospective yield suddenly takes a fall, the company can find itself with negative net worth. If bonds are utilized, the interest rate may rise, which equates with a decline in the bond price, and if shares are utilized then the share price may slump. The textbook example of risk declining during upswing (Kolb and Rodriguez 1992) may be misleading since actual risk can rise while it does not get priced into the market; but when the market is cognizant of the rise in actual risk, it can result in quite substantial sudden increases in recognized risk, through negative feedback information flows, due to the prior and current increase in uncertainty.

Other endogenous problems typically emerge during the upswing. For example, higher oil prices due to the expanded demand of the boom or similar excesses; further rising interest rates as monetary authorities try to dampen inflationary forces while firms expand their demand for funds; wages rising and productivity dampening as workers slacken the intensity of their labor due to low unemployment; and rising global conflict as the excesses of the boom lead to a heightening of international tension. In addition, during the height of the boom, finance has a tendency to dominate industry with the rise in unproductive speculation in the stock market, the foreign exchange market and the construction industry.

The result of a combination of these forces is usually a dramatic increase in recognized uncertainty as the prevailing business climate deteriorates, which has the typical response of reducing the prospective yield of investments as business recognizes the heightening instabilities. Fragile growth built on endogenous funds, which outgrows sustainable investment levels leads to a decline in net worth, leading 
to a drop in investment demand as well as consumer demand. It may also have the effect of increasing the supply price (costs) of inputs, leading to a reduction in profit. These demand and supply factors together tend to reduce cash flow and capitalized income, leading to the situation of "Ponzi finance" for many firms:

$$
\begin{array}{cl}
\mathrm{YY}=\text { mCC } & (\text { where } \boldsymbol{m}<1 \& \mathrm{YY}<\mathrm{CC}) \quad(1 \mathrm{c}) \\
\mathrm{K}(\mathrm{YY})=\mathrm{mK}(\mathrm{CC}) \quad(\text { where } \mathrm{m}<1 \& \mathrm{~K}(\mathrm{YY})<\mathrm{K}(\mathrm{CC})) \quad(2 \mathrm{c})
\end{array}
$$

Thus the FIH states that forces endogenous to the cycle lead to anomalous processes that periodically negatively impinge on capitalist growth and development, such as during the mid-1970s, plus the early 1980s, 1990s, and 2000s in most advanced nations. The principle anomaly is that the financing of business occurs in an environment of relative ignorance about the future where there are sudden changes in prospective yield, uncertainty and liquidity preference according to the prevailing business climate. The actual situation can vary according to the institutional and business environment, but the general rule applies through the history of capitalism. Typically, as deep recession commences (during long wave downswing) banking crises arise due to low profit and high uncertainty (Wolfson 1994). With high levels of uncertainty, it doesn't take much for the recession to impact negatively on financial institutions - through, for instance, a sudden drop in prospective yield for certain critical financial institutions - and for this to synergistically feed back negatively to industry, and so on ad infinitum. Lenders of last resort facilities and big government - introduced over the past seventy years - have been historically necessary to prevent the instabilities from leading to depression. This endogenous instability method is similar in many respects to the non-equilibrium growth and cycle work of Nicholas Kaldor (1972), David Gordon (1998) and Howard Sherman (2003).

\section{Contradictory Dynamics and Cumulative Causation}

\section{Disembedded Economy}

It is generally agreed by heterodox economists that the raw workings of capitalism would see a heightening of the cyclical process as well as the pattern of inequality and uneven development. Karl Polanyi (1944) saw this in relation to the principle of the disembedded economy, where capitalism in its pure form ravages the social, cultural, and ecological environments in the pursuit of accumulation and profit (Stanfield 1986; 1995). The search for private reward in the form of profit, rent and interest tends to result in the global and regional movement of capital and the destruction of transactions that are not market-oriented. Cultural peculiarities are obliterated, families destroyed, the environment ravaged, and stability upset in the name of progress. Thus, the global workings of the capitalist process have a dark side, inextricably linked to creative destruction.

Indeed, the pure market system could not survive and would destroy itself under the impact of its motion. This leads to a "double movement," namely, that for 
capitalism to reproduce in an ongoing fashion requires both the propagation of markets in addition to the establishment of a protective response in the form of institutions to sustain the social fabric to reduce uncertainty and contribute to the long-term reproduction of capitalism's conditions of existence. What this effectively means is that for the control of capital and markets to survive in the long-term requires certain institutions to protect the market and capital from itself. For instance, systems of innovation, market niches, and internal corporate networks are established which create structured environments and potentially embedded processes.

The principle of hysteresis maintains that forces underlying supply and demand are affected fundamentally by past states, processes, and expectations. For instance, a drop in investment leading to reduced demand will not return the economy to full employment equilibrium because such movements take time, and in the interim may lead to deterioration in the skill base as unemployment affects the economy permanently. Under free markets the path dependent "lock in" of technology can operate, leading to sub-optimal efficiency. A large reduction in tariffs in the short run may lead to stagnation of the agricultural sector, which can permanently affect unemployment and growth unless carefully managed. A cold turkey approach to reform of transitional economies can lead to major macroeconomic dislocation due to the emergence of institutional instability.

Pure market systems would fail to provide the public goods or systemfunctions required for long-term growth and accumulation. The development of institutions are required for the circuit of capital to adequately solve the systemproblems of coordination, management, aggregate demand, productivity, labor power supply, and leadership. The coordination of economic processes is required in light of the geographical, political, cultural and complex organization of the global and national economies. Management is necessary for corporations that seek to moderate the uncertainty of the market and benefit from economies of scale and scope. Due to problems of over-production and under-consumption, an insufficiency of aggregate demand requires both automatic and (intelligent) discretionary stabilizers and a lender of last resort to prevent major dislocation. To ensure the extraction of labor effort from workers; systems of corporate organization and supervision have emerged. To ensure the availability of suitable labor power; effective families, schools and universities are necessary. To provide leadership for the global system; structures of command and power are periodically necessary from dominant nations, preferably in the form of "soft power."

This leads us to the principle of social structure, namely, that formal or informal institutions are necessary to solve many of these public goods questions underlying accumulation. Individuals do not always operate efficiently and fairly from the point of view of system reproduction. They often have inadequate knowledge, narrowly formulated actions, and their rationality is heavily bounded. To help solve problems of information, knowledge, cooperation and coordination, institutions are necessary to reduce transaction costs, enable cooperation, agreement or coercion, and provide goods and services inadequately generated by "the market." In short, certain institutions may provide the structure and stability lacking from "pure" market 
relations. The themes that institutionalists have been developing for over a century have become accepted knowledge among our seven sub-groups, but also in a wider arena. ${ }^{10}$

\section{Evolutionary Long Waves of Institutions}

This leads to modern work on the regulation and social structures of accumulation schools of political economy. The regulation approach sees the historical tendency for various global, regional and national modes of regulation, comprising both a regime of accumulation and a number of institutional forms (Boyer and Saillard 2002). The regime of accumulation includes both the production style, which must satisfy the system-requirements of sufficient conflict resolution, and productivity; while the mode of regulation of consumption satisfies the requirements for sufficient aggregate demand. If the fusion of the production style and mode of consumption reproduce sufficient productivity and demand then the dominant requirements are met for long wave upswing. However, certain supplementary institutions are necessary to contribute to the reproduction of system-functions. For instance, a global regime of international relations and trade must promote leadership for the viability of the world system. A financial system is required to promote sufficient stability, resolution of conflict between business and industry, and the supply of finance for industry and consumers. A governance regime is necessary to supply enough aggregate demand and income support for social accumulation, and a family-community regime is required for social stability, trust and relative equality. If these institutions support the regime of accumulation sufficiently then the mode of regulation will enable long-term growth and development to occur.

The social structure of accumulation (SSA) approach takes a similar view to long waves as the regulation school, although the priority is given to the institutions (Gordon 1998). A cluster of institutions is thought necessary to promote a new macro, regional or global SSA. The "micro" or individual potential SSAs comprise production-distribution, financial, governance, and family-community institutional spheres in much the same way as in the regulation approach. The principle difference is that with the SSA approach the individual (potential) SSAs have about equal importance, whereas for the regulation school, the regime of accumulation (what SSA scholars may call the production-distribution-consumption SSA) is primary. In the last analysis, primacy must emanate from detailed historico-empirical analysis, rather than appearing a priori.

In terms of whether a new mode of regulation or SSA has emerged for the global economy (or some of the nations), the system as a whole needs to be scrutinized historically through time. The dominant institutions, including technology, ideas and social arrangements, need careful examination in relation to their functioning, contradictions and transformation. It is a controversial subject, since the first group of political economists believe that a new long wave upswing has already emerged for the United States and (possibly) global economies. For instance, Victor Lippit (1997), Bahzad Yaghmaian (1998), plus Ismael Hossein-zadeh and Anthony Gabb (2000) all 
believe that a new long wave upswing has emerged, even if some of them have caveats and qualifications about it. They all believe that the trend to globalization, neoliberalism, free markets and corporate restructuring has enabled the system to expand the circuit of social capital through a more unadulterated form of capitalism. Reestablishing the conditions for private profit, initiative, innovation, and competition has given capitalism a spiritual renewal to regenerate its growth and accumulation through positive feedback loops.

On the other hand, a second group, includiung Michel Aglietta (1998), Robert Brenner (2000) and Phillip O'Hara (2000) argue that long wave upswing is unlikely to be in motion because the contradictions of neoliberal capitalism impose severe limits on accumulation and growth through the circuit. The very things the first group argues help capitalism; the second group argues hinders it. The dominant contradictions include insufficient aggregate demand, financial instability, distorted leadership, declining trust and association, and excess conflict. The principle of contradiction is critical for comprehending the endogenous discontinuities, instabilities, and conflicts of contemporary capitalism. Every social system has its contradictory relationships that both enable and hinder reproduction, even when growth and accumulation are generally quite strong. The real difficulty is differentiating between contradictions that - on balance and in the long-run - act positively vis-à-vis those that act negatively on the reproduction process as a whole. This assessment is the main difference between those who argue that neoliberalism and deregulation are helping capitalism and those who believe they are hindering it; quite apart from the other question of whether a progressive political economy is being developed through globalization and neoliberalism (see O'Hara 2006b).

SSA and regulation schools of political economy have modified the original neo-Marxian framework by deepening the role of institution-evolutionary themes complementary to institutional post Keynesians, radical institutionalists, institutionalradical feminists, socioeconomic institutionalists and EAEPE Schumpeterians.

\section{Circular and Cumulative Causation}

To understand the pattern of reproduction, contradiction, and change, IEPE makes use of empirical material through the analysis of "stylistic facts": historically specific regularities that may be subject to change, but are likely to remain in force in the foreseeable future. It also can make use of quantitative methods, especially where an array of variables are included in endogenous models of production, distribution, exchange, and reproduction. Multi-causal models of symbiotic interaction and feedback are critical to our seven sub-groups of IEPE. Especially important are models that recognize the principle of circular and cumulative causation (CCC) underlying growth, accumulation, and distribution. Two varieties of CCC exist, one links to Kaldorian notions of growth and accumulation, while the other involves a Myrdalian analysis of social inequality and institutional change. The similarities between the two views are that they both situate the economy within a system of interdependencies between variables and instability of motion. 
For instance, the Kaldorian system of CCC can be used to explain the workings of the regime of accumulation in regulation analysis. Consider Figure 5, which examines the workings of aggregate demand, productivity and innovation in mutual interdependency.

Usually the CCC model is used to explain accelerating accumulation and/or decumulation (Pini 1995; O'Hara 2001). This mode of explanation concentrates on positive feedback among the principle variables, shown in rectangles. Here, aggregate demand is the generator that stirs the system into motion. Investment, consumption, government spending and net exports represent the monetary stimuli propelling productivity and innovation. Before investment can be stimulated, a level of stability and certainty is required, whereby optimistic expectations of the business climate reproduce high levels of prospective yield into the foreseeable future. In a climate where uncertainty is moderated through institutions, organizations, and routines, investment can be generated to propel productivity and innovation. Productivity is stimulated through economies of scale/scope, learning by doing and ensuring that labor is extracted through systems of supervision and control, or alternatively through efficiency wages and a positive work environment. Productivity is also promoted through innovation, based on the application of new ideas, which are endogenous to the system as the availability of finance enables entrepreneurs to put into practice new methods, products, markets and raw materials. Higher productivity and quality products then stimulate net exports in the world market (especially if world income is

Figure 5. Kaldorian Circular-Cumulative Causation with System Dynamics Feedback

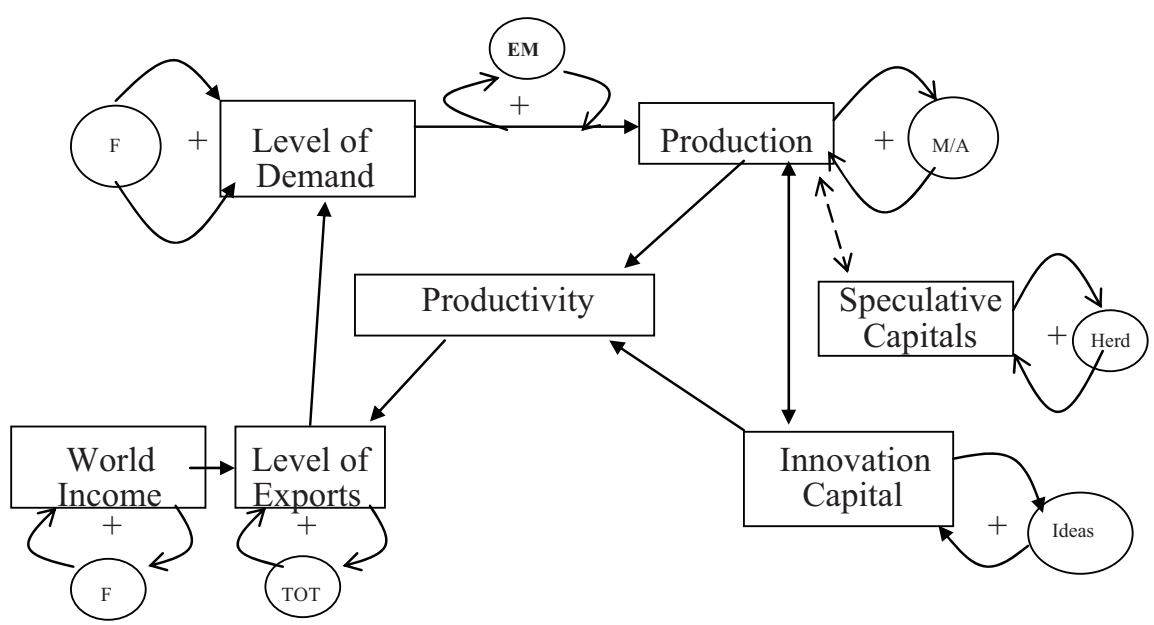


being increased), leading again to higher levels of demand and hence investment and growth in a circular and cumulative fashion, and so on through many rounds of circular motion. (Downswings also operate, as these CCC processes can operate in reverse.)

The standard Kaldorian CCC model is a positive feedback, self-reinforcing system, which may help explain continuing growth or decline, depending on the state of uncertainty, investment and aggregate demand. To transform circular and cumulative dynamics into more (amplified) cyclical dynamics requires the introduction of additional system dynamics feedback processes, through, for instance, business or government (Sterman 2000). This is done by the introduction of system dynamics feedback loops concerning physical growth, information and decision-rules into the behavioral relationships involved in institutions (Radzicki and Sterman 1994). The introduction of circular loops in Figure 5 provides a simple example of what happens when such human intervention is introduced in the form of government and business decisions.

Six realistic system dynamics feedback processes are introduced into Figure 5 (that are important to heterodoxy), thus modifying the behavioral relationships underlying the Kaldorian CCC process. First, a system of automatic fiscal stabilizers (F) is introduced in the form of government unemployment and social security payments that are specifically linked to the state of aggregate demand and uncertainty. This is introduced domestically and globally. The impact of these measures is to moderate the cycle and reduce (de)cumulative instability.

Second, endogenous money and credit (EM) of a structural and accommodative nature are introduced, which provide finance for production, speculative capitals, and innovation. This introduces cycles into the framework by over-expanding production and speculation during the upswing above fundamentals, especially in speculative activities, which raises the level of Ponzi finance, leading to successive waves of overexpansion and decline.

Third, a multiplier and accelerator system is introduced (M/A), which introduces the behavior of consumer demand, investment, and stock-inventory adjustment. By itself the accelerator enhances investment through a positive loop (caused by greater demand and the multiplier), until the required capital stock is reached.

Fourth, we introduce a degree of herding behavior in the stock market (Herd), which is an increasing positive function of the rate of growth of aggregate demand. This factor also increases the periodicity and amplitude of the cycle as Ponzi finance creates bubbles, followed by crashes and deep recessions, which aid the generation of hedge financial positions.

Fifth, we introduce the application of new ideas (Ideas), which enhance productivity through more productive methods and systems of organization for management. When these ideas are applied new systems of production, markets, consumer satisfaction, organization and raw materials are realized in the capitalist process. This may engender monopoly rents, followed by a degree of competition as the methods become more universal. 
Last, a terms of trade effect (TOT) is introduced in the form of the dynamics associated with the Prebisch-Singer hypothesis, impacting on exports. This impacts through a tendential relative decline in primary product export prices (and mass production manufacturer) divided by high-technology prices; as well as a greater level of volatility in the prices of primary commodities compared with other exports. This effect expands both the degree of volatility in the world economy and the level of uneven development between center and periphery.

Taken together, these six feedback systems promote circular and (de)cumulative motion. When volatility is introduced into the processes cycles and waves can be explained, which can enhance the level of realism of the model. The subschools of IEPE, however, do not just specialize in the CCC of growth, (dis)accumulation and cycles/waves, somewhat narrowly viewed, but also the social and institutional foundations of development and standard of living. Perspectives of CCC influenced by Gunnar Myrdal's studies of African Americans and Asian development seek to isolate these factors in the process of social and cultural change. Figure 6 illustrates how this can be viewed.

Figure 6. Myrdalian Circular-Cumulative Causation with System Dynamics Negative and Positive Feedback

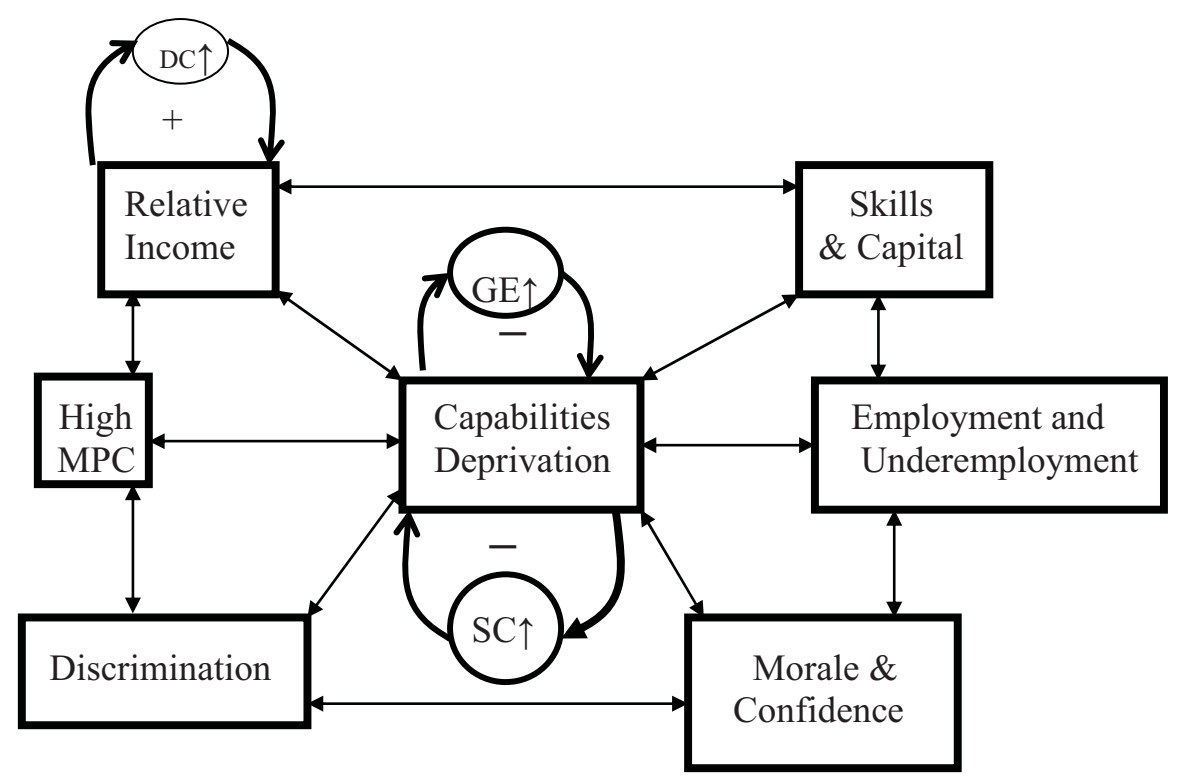


First, we examine the purely cumulative dynamics of (social) CCC, then introduce additional system dynamics feedback loops to enhance the degree of realism of the process. We start then, by viewing only the linkages between the rectangles. Here, the general process of acquisition of capabilities is a dominant factor linking the interacting factors that influence development. Capabilities are the myriad of abilities that enhance social, economic, and political freedom (Sen 1999); nutrition, education, and emotional development; plus the facilitation of institutions that enhance movement, communication, and networks for pursuing life in a complex world. Inhibiting capabilities lead to low income, employment, morale, confidence, and discrimination. This in turn adversely affects capability levels (in a positive feedback manner). Greater gender, ethnic and class discrimination negatively affects income, morale, employment, and skill, and thus reinforces discrimination in the lowest segment of the labor market. Low relative and absolute income contribute to capabilities deprivation, shortage of skills, and ultimately more unemployment and underemployment, which negatively affects income, and so on, ad infinitum through circular and cumulative motion.

In a system of status emulation, low relative income necessitates a high marginal propensity to consume, since to emulate the rich, those lower in the pecking order need to spend a much greater proportion of their income (Veblen [1899] 1965; Duesenberry 1958). Conspicuous consumption creates demonstration effects that impact social habits and practices. Indeed, habits - personal and social - are critical to the whole circuit of reproduction, since they enable (or inhibit) skill formation, transaction costs, and forms of regularity for moderating uncertainty and instability (Waller 1982; Hodgson 1994). Habits are better if they have an element of potential flexibility, being somewhat adaptable to different situations. The critical habits are those relating to the household, social relations, the work environment, education and thought.

Again, system dynamics stock-flow feedback processes can help add complexity and realism to the social-institutional aspects of CCC. Now we introduce three circular loops, including two "negative feedback" and one "positive feedback" effects, into the model. The first negative feedback factor is a government program of spending on greater educational enhancement for the lowest classes (GE $\uparrow$ ). The second is a government attempt to audit and enhance the social capital of trust and networks of association among the lowest classes; including a system of microfinance to aid fledging business networks among the poorest of the poor ( $\mathrm{SC} \uparrow)$. The third variable, positive feedback is an amplification factor associated with conspicuous consumption and general demonstration effects (DC $\uparrow$ ) due to cultural factors, which has the result of enhancing the relative income of the upper classes.

The long-term introduction of two negative feedback policy measures (education and social capital) may reduce the decumulative relative capability tendency among the poorest of the poor, as they enhance the relative capabilities and hence skills, capital levels, employment, morale and confidence for the very poor. In this instance, the positive feedback impact of greater conspicuous consumption and demonstration effects among all classes', results in lower-class relative depravity. 
Overall, while the two negative feedback processes may enhance relative lower class positions, the high-impact positive feedback effects of conspicuous consumption may outweigh the negative feedback processes. Being caught up in conspicuous consumption and emulation games may increase systemic waste in the community as people try to outdo each other in the competitive stakes.

\section{Institutions, Habits and Instincts}

The invidious institutions and relative income leads us to a critical aspect of contemporary IEPE - the nexus between institutions, habits, and instinctual propensities. This nexus is critical to the social psychology of the political economy. Institutions are those social patterns of interaction that structure behavior and thought. They can be formal or informal in nature, and constitute the social cement whereby people interact with others in all facets of life. Habits are those individual patterns of regularity formed in order to make order out of the apparent chaos of the world. They arise out of action and are ingrained in the thought and behavior of the individual. Instincts are propensities that give an innate potentiality to human endeavor, formed from millions of years of evolution through selection, adaptation and variety. They provide a foundation for human action, from the basics of survival to the nurturing of the young to the creation of novel solutions and participation in status-emulation and war. (O'Hara 2002; Hodgson 2004).

Together this nexus of institutions-habits-instincts establishes a powerful fabric of individual and social forces propelling human action. The individuality of humanity exists within the context of instinctual potentiality and action, the need for habituation and the influence of institutions. The principle of bounded rationality is critical, in this context, since individuality seeks resolution through flexible regularity of behavior in order to exist in an uncertain environment. Human beings are essentially action-centered, under the influence of propensities, protective responses, and collective structures. Action, creativity, and novelty are enabled and channeled through a myriad of forces that abstract from a technical assessment of benefits and costs. In an uncertain environment, where individuals are ignorant of the future, decisions tend to be made based on the prevailing business climate. Individuals tend to seek the general benefits of working in company with others (often in competition with other groups and individuals) so as to reduce uncertainty, benefit from diversification, institutionalized knowledge, and lower transaction costs. Actions and decisions are made in a social environment under the impact of group decisionmaking and individual propensities.

In such an environment, change and evolution are not only circular and cumulative, and cyclical and wave-like, but also complex, subject to both blind drift, and directed motion (Jennings and Waller 1994). Economic evolution is heavily affected by the drift of institutions, under the impact of evolutionary processes such as selection, adaptation and the emergence of variety. The selection process is bounded, yet the advancement of knowledge provides alternatives and ways of adapting the current environment to future potentialities. The emergence of the "knowledge 
economy" in recent years must be situated in this context of bounded potentiality. While individual decisions may have an end in mind, they are set within the evolutionary process of the institutions and the course of the transformation cannot be predicted with any certainty. This is because there is a difference between individual and social processes, the complexity of the latter tending to blindly drift through time. Hence the recognition by many scholars for changes to have unforeseen affects on the macro and global economy.

\section{Principles of Institutional Change}

This leads us to three principles of institutional change (Bush 2001; Bush and Tool 2003). The first is the principle of ceremonial encapsulation. This means that progressive change of the social and political economy may be inhibited or tempered by the vested interests holding the commanding heights of power. The possession of power gained through struggle, enterprise, privilege, and inheritance can become "locked in" such that changes that enhance development may be inhibited. Certain classes, ethnicities, gender, and groups may block social innovations in order to prevent a loss of power and prestige (Adkisson 2004). Such power can be encapsulated in the institutions so that it is perfectly legal, politically acceptable, and seen as "natural." The established hegemonic cultural systems of collective behavior are made possible through the workings of certain "enabling myths" that the population come to believe in (Dugger and Sherman 2000, ch. 4). They may include the myth that the assertive use of power can justify the ends if it does not violate any statute associated with fraud, antitrust, civil and common law.

The second is the principle of recognized interdependence, which states that individuals will be able to contribute toward progressive institutional change, and manage the ramifications of such change, if they have a broad knowledge about the structure and evolution of the social and natural environment. Individuals that are inculcated with the knowledge necessary to comprehend the patterns of interdependency existing within the real world are better able to contribute to and cope with change. In particular, if they are able to understand some of the complexity of institutions and the problems involved in change, they may be able to modify their behavior to suit the broader modifications being undertaken. Thus, the supply of information and knowledge has definite public goods type functions that make an argument for universal lower, intermediate, and advanced education quite persuasive.

The third is the principle of minimal dislocation. This recognizes that the environment within which individuals operate predicates varying levels of uncertainty, lack of information and indecision. It also recognizes the extent to which the parts of the social economy are interdependent and connected. Hence, a change somewhere along the line will, with various feedback loops, impact on the other parts of the system. Through the impact of positive-policy loops even progressive changes ("from above") may instigate quite major transformations of the system; leaving many people confused and lacking in resources to cope with the magnitude of the required changes to their lifestyle. The cumulative nature of the changes may create an environment 
that dislocates many of the necessary as well as ceremonial parts of the system, thus upsetting the process of reproduction. This could apply to things such as technological and institutional changes, policies concerning transitional economies, social policies, and the like. Therefore, it is critical when dealing with change to take into account the ability of individuals to adjust and to provide enough resources to aid their adaptation to the new conditions. This can take the form of information, resources, and network-generation that make the transition more humane and trustworthy. ${ }^{11}$

\section{Policy and Governance}

There is much convergence between the sub-schools of institutional-evolutionary political economy vis-à-vis basic principles of inquiry. They all seek a realistic, institutionally rich, dynamic view of the economic process set in a social and ecological environment. Each of them concentrates on special themes while being forced by the weight of evidence and interaction among other scholars to spread beyond this to a broader view of the economy. The interaction between them at conferences, in journals, in the editing of books, and in academic departments has seen much convergence over the past forty years. Overall, they tend to have an increasingly shared vision of the instituted economy in evolution through historical time.

\section{Progressive Agenda for Change}

In matters of policy and governance, all seven sub-groups of IEPE support a broadly left-of-center program that includes a combination of community, workplace, and family participation in matters that affect their lives. In particular, IEPE seeks to promote democratic inclusion for those who traditionally have been denied the power to improve their livelihood beyond the basics. For them, it is critical to go beyond mere formal democracy of having the right to be involved in electoral matters, to the right of citizens to be actively engaged in the economic process through participatory democracy in the dominant institutions. This involves devolving more power to those who lack adequate resources to become involved meaningfully in the processes of production, distribution, exchange and governance. For instance, there are major similarities between the egalitarian programs advocated by progressive institutionalist Marc Tool (2001), institutional Marxists Bowles, Gordon and Weisskopf (1990), post Keynesian institutionalists (JPKE 2004-2005), and institutional-radical feminist perspectives on capabilities and fundamental entitlements (Feminist Economics 2003).

Looking at broad governance issues, there are six major areas where most of the sub-schools are likely to be in broad agreement.

1. Governance is endogenously linked to institutions;

2. Governance is linked to numerous potential institutions; 
3. Governance is related to the destructive aspects of the 'disembedded economy';

4. Governance is associated with the need to moderate uncertainty;

5. Governance links to the potential conflict between capital and labor;

6. Governance links to the potential conflict between industry and business.

The first area concerns the recognition that established governance patterns are endogenously linked to the dominant institutions of the system, and cannot be seen as apart from them as an independent umpire. Governance structures and processes are part and parcel of these dynamic and contradictory forces, and hence to some degree have difficulty overseeing the social and economic system from above. Current governance processes are thus imbedded in the system of norms, institutions, habits and privileges of the system. This is true regardless of whether governance emanates from governments, corporations, families, or non-government organizations. It is impossible to organize governance in such a way that it operates above the system and in abstraction from its many negative (and positive) aspects.

\section{Trust and Community}

Given that, the second lesson of governance is that it can reside in any institution, and need not necessarily be activated by government. We need efficient and equitable institutions concerning households, production, distribution, finance, and the state. We need a whole set of institutions that operate well within the context of the environment in place and emerging in the future. This requires, at the general social level, a high degree of trust, association, and community. This is preferable to a system dominated by laws, regulations, and armies to ensure that people do what is required, since these repressive measures are likely subject to abuse, self-interest, corruption, plus exploitation by the vested interests. We could say that there is an element of libertarianism in heterodoxy, which is influenced by liberalism and anarchism, given their systematic critique of Stalinism and the classical Keynesian welfare and regulatory state.

We realize more than ever the importance of trust, association, and community. Any economy lacking in these qualities is not going to function very well. Yet, it is difficult to design appropriate policies to these matters, unless perhaps, they are in the forefront of policy concern, and exhaustively examined with the help of many teams of scholars and practitioners. Much evidence supports the conclusion that the past three decades of capitalist development has seen a shift of resources from family, society and ecology to market, corporation and finance at the national, regional, and global levels. In many of the nations studied, aggregate socioeconomic performance has not improved since the mid-1970s, and measurement of the declining social resources is in an early stage of development (O'Hara 2006b, ch. 2). A critical policy issue is the need for much better information and surveys on the 
relative movement of resources from social and environmental, to corporate and market relations.

\section{Destructive Creation}

There are several strands of IEPE that argue the case for economic growth being merely the process of transferring social and environmental resources to specific corporations, markets, groups, and individuals. These strands include Polanyi's disembedded economy, Marx's notion of destructive creation, the Foster-Bush-Tool theory of instrumental and ceremonial functions of institutions, Edward Nell's theory of transformational growth, and ecological views of strong sustainability. Capitalist growth is ultimately dependent upon the creation of new products, processes, markets, and relationships, while at the same time destroying old products, processes, markets, and relationships. Destructive creation is forever making and breaking technologies, institutions, and ways of operating. Creative destruction is exploitative in destroying non-market activities while extending markets. Scholars have been trying to calculate the destruction wrought on social and natural resources to provide a balanced assessment of growth and development (see O'Hara 2004b). A policy requirement is for this research to proceed at a faster pace and for the implications to be taken seriously once they are suitably analyzed. However, the ceremonial encapsulation and recognized interdependence limits the degree to which this is possible.

Important in this respect, are the principle of entropy and the so-called laws of thermodynamics (Georgescu-Roegen 1971; Khalil 2004). The first law says that energy can be neither created nor destroyed, while the second says that energy tends to become increasingly unavailable in a closed system. The Earth as a whole is an open system due to the impact of the sun. But entropy - the second law - does impact to some critical degree. Economic activity cannot create energy and thus produces negentropy. In essence, it destroys environmental resources and biodiversity. The second law also explains the limits of recycling resources. Important for policy, is the notion of strong sustainability, where governance systems are required to take into account the need for minimal dislocation of ecological resources, rather than to trade off between ecological and durable fixed capital, for instance; and to supplement GDP-type figures with measures such as the Index of Sustainable Economic Welfare (ISEW) so that a more holistic social policy framework is practiced) (O'Hara 2004b). The precautionary principle also needs to be taken seriously to recognize the lack of knowledge and degree of uncertainty about the ramifications of changes to the ecological environment, which has implications for such things as global warming.

The third policy issue relates to the destructive aspect of transformational and disembedded growth requiring resources to support a more gradual process of transition, to promote minimal dislocation of the system and its component institutions and practices. Hysteresis and path dependency imply that the process of adjustment affects the traverse between two stable states, such that stability may not emerge due to a considerable period of cumulative motion. In the process, in the 
downward direction skills are destroyed, families dislocated, regions depressed and communication systems upset while ever-new arrangements are being formed through other skills, institutions, areas and communication systems. In a very practical sense, it is critical for governments to provide resources in the form of safety nets. With the demise of families, skills, and areas, for many people governments are the only other option, despite the limits of governments already mentioned. Neoliberal governments are not likely to provide many such resources because of their closer relationship to business, especially financial and transnational capital.

Fourthly, some action is needed to reduce the uncertainty inherent in a system of accumulation centered on future prospects that are not known with any certainty. The state, as even conservatives know, is required to provide a system of legality to protect property rights, to support business associations, and ensure that the contract system is firmly embedded in law. Governments need to support the long-term interests of the business system so that investment can be undertaken in the knowledge that credit agreements, investment arrangements and business functions can function relatively smoothly. It is also necessary to prevent widespread fraud, corruption, and cronyism so that a positive business climate can be attained. There must be a certain amount of trust in the institutions of business and government for a positive climate to exist to support long-term accumulation.

However, the sub-schools of IEPE tend to add that the interests of business need to be legitimized through an effective system of citizens' rights. A truly liberal system of governance must provide ordinary people with rights and obligations. They include the right to privacy, the right to protection from assault and battery, the right to vote and be active in politics, the right to freedom of expression and assembly, and the right to a minimum standard of living. These rights can utilize a considerable amount of resources if they are to be truly active rather than merely formal in nature. The obligations include the need to pay adequate taxes when possible, the need to be in accord with other people's rights, and the need to be actively involved in civil activities in proportion to the extent made possible by the rights. The real test of a governance system to be fair and just is the extent to which the protection of property rights and business are balanced by a system of citizens' rights. If property rights and business are supported more than citizens' rights, instability may emerge because the system of governance lacks legitimacy for the people. And, if the rights of citizens are supported more than business - at least under capitalism - it is likely to also lead to instability and decay.

\section{Capital and Labor}

The fifth issue relates to the conflict between capital and labor. This is often partly resolved institutionally through the power of business being moderated by the power of labor unions and the establishment of political parties that especially have the interests of labor in mind. However, the institutional dominance of neoliberalism and industrial metamorphosis has reduced both sources of labor representation, resulting in rising inequality, declining power of workers, and the movement to the right of the 
political spectrum (except in Latin America and Scandinavia). In short, a critical problem at present through the global transformation of capitalism is that the interests of business are ahead of the interests of the common person. The potential problem of legitimacy seems to have been "solved" by the acceptance of this new power arrangement by most. However, other problems remain; anomalies of reproduction caused by a lack of aggregate demand, a shift of government spending from productive to relatively unproductive areas, and financial instability.

\section{Fiscal Policy}

One problem with neoliberalism is the downplaying of fiscal, relative to monetary policy. Numerous studies clearly point to the negative growth impact of the recent switch from productive public capital expenditure to transfer payments. One such study even goes as far as to conclude that all of the 1970s-1990s drop in growth in the United States is due to this switch (Weber 2000). Other, comparative studies, also point to the net crowding-in effects of public capital on private investment, in the form of expenditures on education, health, infrastructure and communications, for a cross section of quite different nations. Transfer payments, on the other hand, tend to crowd-out private investment spending (e.g., Miller and Tsoukis 2001). This points to the global need for more proactive states that initiate productive projects on many fronts, to not only sustain aggregate demand but also to promote private spending and social networks.

These issues lead political economists and others to be highly critical of neoliberal budgetary restraints. Numerous theoretical and empirical studies support notions that saving is stimulated through investment as income increases; that state spending through monetization stimulates private investment visà-vis taxes that represent a financial constraint; and that budget deficits are usually required when demand is inadequate and creates a positive net prospective yield for investment. The sub-schools generally support Abba Lerner's principles of functional finance, namely that state spending should be expanded when demand is inadequate and reduced when high inflation looms, and that a critical function of government is to provide liquidity to the system. On these measures they agree. The main dispute seems to be about how public spending should be activated: whether by providing service employment through employment of last resort (Wray 1998); enhancing productive capitals more directly (Kadmos and O'Hara 2000), or some combination of the two.

\section{Industry and Business}

The sixth issue of intra-class conflict centers on the relationship between industry and business. The last two decades has not only seen a shift in power from labor to capital, but also from industrial capital to finance capital. This has manifested in deregulation of the financial system (both domestically and globally), the importance placed on shareholder value, and a greater significance given to short-term returns to business. While many industries have grown over the past couple of 
decades, particularly computers, services, and tourism, these are all sectors where the productivity gains are difficult to spread through the general economy. Indeed, Robert J. Gordon (2001) and others, argue that productivity has been low because these new sectors are pale imitations of the radical technologies of the past, such as electricity, transportation, the assembly line system, and the internal combustion engine. The periodic emergence of massive speculative bubbles and lack of correspondence between the growth of industry and finance (Binswanger 2000; Stockhammer 2004) over recent decades has led to the dominance of finance over industry. Financial decisions now dominate industrial concerns, rather than the two being balanced, which creates an environment where there is often little relationship between CEO remuneration and long-term profitability. Monetary policy also tends to be unduly influenced by the stock market. Hot global capital flows can destabilize whole regions when uncertainty suddenly rises.

These issues have led to calls for policy measures to moderate such instabilities and intra-class conflicts. One proposal calls for developing nations not to prematurely deregulate before a suitable institutional and governance structure is in place. A post Keynesian strategy is for surplus current account nations to bear the brunt of adjustment through expanding aggregate demand. A well-known one is the introduction of a Tobin tax to provide "grains of sand" into the wheels of international finance to moderate instability. Thomas Palley argues for the need for asset based reserve requirements to moderate bubbles. The "Soros proposal" seeks to establish a Global Central Bank that has powers of money creation and regulation. A general policy proposal is for monetary policy interest targets to be supplemented by a wider range of options and policies (JPKE 2004).

These areas of governance are core areas where the sub-schools agree about broad dimensions of how to improve performance by including the underlings in the economic process in a meaningful way. They seek to challenge the vested interests who gain vast wealth at the expense of meaningful social change. They seriously think community relationships of trust and sociality can be improved, and that the provision of the public goods of education, infrastructure and communications need to be deepened. These measures can help those with few resources to contribute in a creative manner to economic development and progress. Both creation and destruction need to be adequately analyzed and included in official statistics, otherwise, destruction of social and ecological resources will continue unabated. The contradictions of modern capitalism need to be at center stage. Only then will a suitable governance system contribute to long-term sustainable development.

\section{Conclusion}

This paper has sought to examine the major principles of convergence between the seven sub-schools of institutional-evolutionary political economy (IEPE), and to indicate the direction governance could take on the basis of these principles. Political economy is an interdisciplinary study of the agency-structure nexus as it evolves and is transformed through historical time in the pursuit of community, warranted 
knowledge and participation. The principles of IEPE are historically contingent, and often take the form of stylized facts and relatively durable propositions that are nevertheless potentially subject to modification on the basis of further investigation. Political economy is a realist analysis of the structure, contradictions and unstable reproduction of economic systems, paying particular attention to the link between agency and institutions, habits and instincts in an environment of uncertainty, ignorance and bounded rationality.

In the analysis of structure, it pays particular attention to institutions, such as the corporation, state, family, financial system, and global economy as well as the ideological and belief systems that condition the behavior of economic agents. The agents themselves are heterogeneous, being variously affected by the intergenerational influences of class, ethnicity, gender, and species as well as the center-periphery relations of global capitalism. Institutions are the social cement that conditions the roles agents play in economic life. They tend to be fairly durable, having varying levels of flexibility and evolving through historical time. As institutions change, they influence business cycles and long waves, which are part of the process of creative destruction giving capitalism a dynamic, yet unstable form of motion.

IEPE is a dynamic, circuitous perspective on the world in the process of uneven development and varying levels of divergence due to the asymmetric distribution of information, resources, power and networks. It tends to eschew equilibrium analysis in favor of the complex interplay of endogenous forces operating through circular and cumulative causation. History plays a critical role in its theory and practice through the notions of hysteresis and path dependence, as well as a systems view of the economy set in a social and ecological environment. It seeks to be a realistic view of the evolution and metamorphosis of economic systems, recognizing that change is ongoing and, therefore, principles are always in the process of revision and reassessment in light of new evidence and developments.

IEPE, in particular, seeks to be in the service of humanity and the world, paying attention to problems that beset various nations, groups and individuals. Poverty, unemployment, financial crises, recession, species extinction, wars and conflict are some of its principal concerns. The contradictions need a theoretical apparatus to direct research to anomalous conditions, relationships and processes. To demystify surface phenomena, such as the enabling myths and theories created by the culture and powerful groups, IEPE is necessarily realistic and critical in its approach. It refuses to become part of the dominant power structures that require ideological allegiance and apologetic explanations for major social problems. Political economists are rather mostly independent scholars seeking to be part of a wider intellectual community that values critical scrutiny of the dominant institutions.

For policymaking, uncertainty is a fact of life, as is the disembedded economy and the boundedly rational nature of agents. Socioeconomic change is often slow, painful and subject to hysteresis and path dependence. The economic system is thus inherently unstable, or undergoes varying levels of instability through change and metamorphosis. The endogenous processes and contradictions must be scrutinized in order to inform policy judgments and decisions. Policy must also recognize the need 
for agents to more clearly recognize the nature and forces of interdependency, the need for minimal dislocation, and especially how the power structure can encapsulate institutions, including the state and especially financial and corporate systems. Above all, in the contemporary age, governance needs to center on ways of reestablishing trust, association and relative equality in the community. It is no longer valid to privilege a narrow conception of economic growth above a broader view of society and culture.

\section{Notes}

1. There is no doubt some confusion of what to call "heterodox political economy" and what to include in its umbrella. There is much terminological debate and disagreement about this subject. Some prefer to call this heterogeneous group "political economists," while others prefer "heterodox economists." Perhaps the best way to resolve the issue is to call the group "heterodox political economists," including feminist, institutionalist, neo-Marxist, radical, social and neo-Schumpeterian schools. Nowadays there is much interlinking of the schools - especially the first five of these - at conferences and in the journals themselves. For instance, inside the back cover of the Review of Radical Political Economics (RRPE), is a definition of "radical political economy" as "including Marxist, institutionalist, post Keynesian, and feminist" traditions (RRPE 2005, 123). Inside the front cover, the Cambridge Journal of Economics (CJE) includes a statement that it was "founded in the traditions of Marx, Keynes, Kalecki, Joan Robinson and Kaldor" (CJE 2006). Many include the Austrians and Sraffians under "heterodox economics," but this current paper does not do this because it would reduce the degree of continuity of the themes. The paper by Stanfield and Carroll (2004) is a useful analysis of convergence between some of the schools of thought vis-à-vis corporate power.

2. For details of the development and evolution of heterodox political economy, see the theoretical works included in O'Hara (2001), and for an investigation of the main individuals associated with these heterodox ideas, see Arestis and Sawyer (2000). An array of other short and longish encyclopedias and dictionaries has also emerged of late that provide some comprehension of the complex nature of heterodox political economy. See especially: Arestis and Sawyer (1994); Hodgson, Samuels, and Tool (1994); Glasner (1997); Davis, Hands, and Maki (1998); Kurz and Salvadori (1998); Peterson and Lewis (1999); Jones (2001); and King (2003).

3. It was not smooth sailing for many people in heterodox political economy, especially during the early years when there was much discrimination, harassment, and intolerance against them in certain circles. For some detail on this in the United States, see Frederic Lee (2004). For some material on heterodoxy in the postwar era as a whole in the United States, see Lee (2002b).

4. Some relatively recent works that provide an understanding of heterodox political economy, in terms of general principles and ideas, include Jan Kregal (1975); Peter Reynolds (1987); Paul Davidson (1992); Marc Lavoie (1992); W. Brian Arthur (1996); Charles Whalen (1996); Philip Arestis (1997); Jason Potts (2000); Marc Tool (2001); Steve Keen (2001); and Frank Stilwell (2002). There are some similarities between "heterodox political economy" and political economy of the more right wing variety. On the latter, see the compilations of Peter Boettke (1994); and William Shughart and Laura Rassolini (2001). Some authors argue that orthodox economics has (perhaps) sufficiently incorporated some heterodox concerns into their theoretical and empirical framework (see Colander 2002).

5. More generally conceived within the heterodox literature, there are disparate forces, sometimes promoting a degree of divergence, which are not the central focus of this paper. For instance, there are many Marxists continuing to develop a sophisticated analysis of the transformation problem (see Sinha 2000), the nature of which is often problematic from an institutional-evolutionary viewpoint. There are numerous conservative Schumpeterians and Austrians concentrating on the positive elements of creative destruction and market expansion, which tends to ignore the need for embedded institutions through rapid change. Some feminists have followed a neoclassical approach to gender through a market-friendly environment of supply and demand. Groupings of new institutionalists have sought to embed their analysis of institutions and evolution in the workings of property rights, 
social markets and decentralized relationships that are of questionable linkage to our themes. Even within the heterodox institutional-evolutionary trend, there are debates and apparent divergences since they go beyond the sub-schools discussed here.

We recognize these disparate forces and largely exclude them from our analysis. In the case of such classical Marxists, conservative Schumpeterians, Austrians, orthodox feminists and new institutionalists this is easily done since the groupings are not part of our survey. In the case of debates and disputes within the more narrowly defined groupings of original institutionalevolutionary political economists, this would take us far from our territory and has been studied by others (e.g., Mayhew 1987; Gordon 1990; Miller 1998). One thing is relevant though, the strength that some scholars have placed on Veblen's presumed critique of Marx. As O'Hara (1997) points out, this is exaggerated and evades the key issue of Veblen's own "softened materialism," similar to the work of European Marxists such as Antonio Grasmsci and Enrico Ferri.

6. Space is relatively short for a journal article dealing with convergence trends within the various schools of heterodox political economy. For this reason, and due to one anonymous referee's comments, we have delimited the scope of this paper to various scholars and sub-groups within institutional-evolutionary political economy somewhat narrowly viewed. For book-length analyses of convergence and general principles of political economy, see the further work of O'Hara (2000; 2001; forthcoming).

7. As Ofori-Dankwa and Julian $(2001,416-417)$ state: Complex[ity] theory is more contradictory and highlights issues of paradox and complexity inherent in studying organizations. . . . Complex[ity] theory . . . is more paradoxical, richly textured, and multifaceted. . . Theory or research in which scholars attempt to "holistically" describe and understand complicated, multilevel, or multifaceted phenomena is best suited to complex design."

8. On the relationship between agency and structure, see Hodgson (2004) and Davis (2003). This question is a critical one in political economy, since mostly scholars of political economy have taken a methodological structuralist view. Some exceptions are Veblen and some post Keynesians. Recently, scholars have undertaken a major analysis of this question, and this is creating some key developments. In particular, it is seen to be necessary to link the question of individual and structural determination. Indeed, this enables us to solve some old problems, such as being able to introduce endogenous preferences into the analysis of individuals, ones that may be an outcome of both agency and structure.

9. Generalizing the notion of heterogeneous agents, one is able to recognize the existence and impact of different classes of people, including workers and capitalists; lenders and borrowers; and buyers and sellers. These groups are important in the realistic workings of the economic process. It is not just asymmetric information that is important but also differential levels of power, access to resources, social position and legal protection. Heterogeneous agents are also critical to the workings of segmented labor markets, an area developed principally by institutionalists, radical political economists and feminists.

10. The importance of institutions has been the main theme of original institutionalists since the time of Veblen. Of course, it was also a prime emphasis of the classical economists, including Adam Smith, David Ricardo, Thomas Malthus and Karl Marx, who were in large measure institutionalists before the term was created. It is often argued that post Keynesians emphasize the role of institutions more than anything, as do feminists, and certainly radical political economists. So widespread has this acceptance become that Austrians and new institutionalists are widely known to see their importance. There are differences in the ways in which institutions are perceived, with new institutionalists and Austrians often-linking institutions to free market theory, but also to some degree challenging it.

11. These principles of institutional change are linked to the instrumental valuation theory, developed by Marc Tool and Dale Bush and their teachers and students (as well as many others). This theory differentiates between the instrumental and ceremonial functions of institutions. The instrumental functions are those that get the job done (i.e., production, distribution, and exchange), whereas ceremonial functions promote unproductive aspects of these and other activities (status, ceremony, and conspicuous consumption). According to Bush (2001), these two functions are ingrained in every activity, and therefore the critical question becomes the degree of ceremonial dominance of the institutions or technology. 


\section{References}

Adkisson, Richard V. "Ceremonialism, Intellectual Property Rights, and Innovative Activity." Journal of Economic Issues 38, no. 2 (2004): 459-466.

Aglietta, Michel. "Capitalism at the Turn of the Century: Regulation Theory and the Challenge of Social Change.” New Left Review no. 232 (1998): 41-90.

Arestis, Philip. Money, Pricing, Distribution and Economic Integration. London: Macmillan, 1997.

Arestis, Philip, and Malcolm Sawyer (eds.). The Elgar Companion to Radical Political Economy. Aldershot, UK and Northampton, MA: Edward Elgar Publishing, 1994.

- . A Biographical Dictionary of Dissenting Economists, $2^{\text {nd }}$ edition. Aldershot, UK and Northampton, MA: Edward Elgar Publishing, 2000.

Arthur, W. Brian. Increasing Returns and Path Dependence in the Economy. Ann Arbor: University of Michigan Press, 1996.

Atkinson, Glen. “Common Ground for Institutional Economics and System Dynamics Modelling." System Dynamics Review 20, no. 4 (2004): 275-286.

Barnes, William, Myles Gartland, and Martin Stack. "Old Habits Die Hard: Path Dependency and Behavioral Lock-in.” Journal of Economic Issues 38, no. 2 (2004): 371-377.

Binswager, M. "Stock Returns and Real Activity: Is There Still a Connection?" Applied Financial Economics 10, no. 4 (2000): 379-388.

Boettke, Peter J. (ed.). The Elgar Companion to Austrian Economics. Cheltenham, UK and Northampton, MA: Edward Elgar Publishing, 1994.

Bowles, Samuel. Microeconomics: Behavior, Institutions, and Evolution. New York: Princeton University Press, 2004.

Bowles, Samuel, David M. Gordon, and Thomas Weisskopf. After the Waste Land: A Democratic Economics for the Year 2000. Armonk, NY: M.E. Sharpe, 1990.

Boyer, Robert, and Yves Saillard (eds.). Regulation Theory: The State of the Art. London and New York: Routledge, 2002.

Brennan, Andrew. "Environmental Problems of the World: Global Warming and Declining Biodiversity." In Global Political Economy and the Wealth of Nations: Performance, Institutions, Problems and Policies, edited by Phillip Anthony O'Hara. London and New York: Routledge, 2004.

Brenner, Robert. The Economics of Global Turbulence. London: Verso, 2000.

Bush, Paul Dale. "Institutional Change and Adjustment." In Encyclopedia of Political Economy, edited by Phillip Anthony O’Hara. London and New York: Routledge, Paper edition, vol. 1, 2001.

Bush, Paul D., and Marc Tool. "Foundational Concepts of Instrumentalist Policy." In Institutional Analysis and Economic Policy, edited by Marc Tool and Paul Dale Bush. Boston and London: Kluwer Academic Publishers, 2003.

CJE. "Editorial Statement." Cambridge Journal of Economics 27, no. 1 (2006): inside front cover.

Clark, Charles M.A. "Political Economy: Schools." Encyclopedia of Political Economy, edited by Phillip Anthony O'Hara. London and New York: Routledge, 2001. Paper edition.

Colander, David. The Complexity Vision and the Teaching of Economics. Cheltenham, UK and Northampton, MA: Edward Elgar Publishing, 2000.

—. Participation in the Cutting Edge of Economics: Roundtable, Eastern Economic Association, Session 91. Boston, March 15-17, 2002.

Davidson, Paul. International Money and the Real World, $2^{\text {nd }}$ edition. New York: St. Martins Press, 1992.

Davis, John B., D. Wade Hands, and Askali Maki (eds.). The Handbook of Economic Methodology. Cheltenham, UK and Northampton, MA: Edward Elgar Publishing, 1998.

Davis, John. The Theory of the Individual in Economics. London and New York: Routledge, 2003.

Downward, Paul, John H. Finch, and John Ramsay. "Critical Realism, Empirical Methods and Inference: A Critical Discussion.” Cambridge Journal of Economics 26, no. 4 (2002): 481-500.

Drentea, Patricia, and Melinder A. Goldner. "Caregiving Outside of the Home: The Effects of Race on Depression.” Ethnicity and Health 11, no. 1 (2006): 41-57.

Dugger, Willam M., and Howard J. Sherman. Reclaiming Evolution: A Dialogue Between Marxism and Institutionalism on Social Change. London and New York: Routledge, 2000.

Duesenberry, James S. Business Cycles and Economic Growth. New York and London: McGraw-Hill, 1958. 
Dutt, Amitava Krishna (ed.). The Political Economy of Development, 3 Volumes. Cheltenham, UK and Northampton, MA: Edward Elgar Publishing, 2003.

Ferrari-Filho, Fernando, Octavio Augusto Camargo Conceição "The Concept of Uncertainty in Post Keynesian Theory and in Institutional Economics." Journal of Economic Issues 39, no. 3 (2005): 579. 594.

Feminist Economics. “Special Issue on Amartya Sen's Work and Ideas: A Gender Perspective." Feminist Economics 9, nos. 2-3 (2003): 1-332.

Finch, John H. "The Role of Grounded Theory in Developing Economic Theory." Journal of Economic Methodology 9, no. 2 (2002): 213-234.

Forrester, Jay W. "Dynamic Models of Economic Systems and Industrial Organizations.” System Dynamics Review 19, no. 4 (2003): 331-345, [1956].

Georgescu-Roegen, Nicholas. The Entropy Law and the Economic Process. Cambridge, MA: Harvard University Press, 1971.

Glasner, David (ed.). Business Cycles and Depressions: An Encyclopedia. Cheltenham, UK and Northampton, MA: Edward Elgar Publishing, 1997.

Gordon, David M. Economics and Social Justice: Essays on Power, Labor and Institutional Change, edited by S. Bowles and T. Weisskopf. Cheltenham, UK and Northampton, MA: Edward Elgar Publishing, 1998.

Gordon, R. J. “Does the 'New Economy' Measure Up to the Great Inventions of the Past?" Journal of Economic Perspectives 14, no. 4(2001): 49-74

Gordon, Wendell. “The Role of Tool's Social Value Principle.” Journal of Economic Issues 24, no. 3 (1990): 879-886.

Gruchy, Allen. Modern Economic Thought: The American Contribution. Clifton, NJ: Augustus Kelley, [1947] 1967.

Hodgson, Geoffrey M., Warren J. Samuels, and Marc R. Tool (eds.). The Elgar Companion to Institutional and Evolutionary Economics, 2 volumes. Cheltenham, UK and Northampton, MA: Edward Elgar Publishing, 1994.

Hodgson, Geoffrey M. "Habits." In The Elgar Companion to Institutional and Evolutionary Economics, edited by Geoffrey M. Hodgson, Warren J. Samuels, and Marc R. Tool, 2 vols, 302-305. Cheltenham, UK and Northampton, MA: Edward Elgar Publishing, 1994.

- Reconstructing Institutional Economics: Evolution, Agency and Structure in American Institutionalism. London and New York: Routledge, 2004.

Hossein-zadeh, Ismael, and Anthony Gabb. "Making Sense of the Current Expansion of the U.S. Economy: A Long Wave Approach and a Critique.” Review of Radical Political Economics 32, no. 3 (2000): 388 397.

Jennings, Ann, and William Waller. "Evolutionary Economics and Cultural Hermeneutics: Veblen, Cultural Relativism, and Blind Drift." Journal of Economic Issues 28, no. 4 (1994): 997-1030

Jones, R. J. Barry (ed.). Routledge Encyclopedia of International Political Economy. 3 vols. London and New York: Routledge, 2001.

JPKE. "International Financial System Reform." Special issue of the Journal of Post Keynesian Economics 27, no. 4 (2004): 551-712.

—_. "The Washingotn Consensus, Neoliberalism and Beyond." Special Issue of the Journal of Post Keynesian Economics 27, no. 2 (2004-2005): 187-365.

Kadmos, George, and Phillip Anthony O'Hara. “The Taxes-Drive-Money and Employer of Last Resort Approach to Government Policy." Journal of Economic and Social Policy 5, no. 1 (2000): 1-22.

Kaldor, Nicholas. "The Irrelevance of Equilibrium Economics." The Economic Journal 82, no. 4 (1972): 312 337. Reprinted in Nicholas Kaldor, Economics Without Equilibrium. Cardiff University: University College Cardiff Press, 1985.

Kapp, K. William. "In Defense of Institutional Economics.” Swedish Journal of Economics 70, no. 1 (1968): 1. 18.

Keen, Steve. Debunking Economics: The Naked Emperor of the Social Sciences. New York and London: Pluto Press, 2001.

Keynes, John Maynard. The General Theory of Employment, Interest and Money. London: Macmillan, 1936.

Khalil, Elias L. "The Three Laws of Thermodynamics and the Theory of Production." Journal of Economic Issues 38, no. 1 (2004): 201-226. 
King, John (ed.). The Elgar Companion to Post Keynesian Economics. Cheltenham, UK and Northampton, MA: Edward Elgar Publishing, 2003.

Kolb, Robert W., and Ricardo J. Rodriguez. Principles of Finance, $2^{\text {nd }}$ edition. Lexington, MA: D.C. Heath and Company, 1992.

Kregal, Jan. The Reconstruction of Political Economy: An Introduction to Post-Keynesian Economics, $2^{\text {nd }}$ edition. London: Macmillan, 1975.

Kurz, Heinz D., and Neri Salvadori (ed.). The Elgar Companion to Classical Economics. Cheltenham, UK and Northampton, MA: Edward Elgar Publishing, 1998.

Lavoie, Marc. Foundations of Post Keynesian Economics. Cheltenham, UK and Northampton, MA: Edward Elgar Publishing, 1992.

—. "Post Keynesian Consumer Theory: Potential Synergies with Consumer Research and Economic Psychology." Journal of Economic Psychology 25, no. 5 (2004): 639-649.

Lawson, Tony. "The Nature of Post Keynesianism and its Links to other Traditions: A Realist Perspective." Journal of Post Keynesian Economics 16, no. 4 (1994): 503-538.

Lee, Frederic S. "Theory Creation and the Methodological Foundation of Post Keynesian Economics." Cambridge Journal of Economics 26, no. 4 (2002a): 789-804.

—. "Mutual Aid and the Making of Heterodox Economics in Postwar America: A Post Keynesian View." History of Economics Review no. 35 (2002b): 45-62.

—. "To Be a Heterodox Economist: The Contested Landscape of American Economics, 1960s and 1970s." Journal of Economic Issues 38, no. 3 (2004): 747-763.

Lippit, Victor. "The Reconstruction of a Social Structure of Accumulation in the United States." Review of Radical Political Economics 29, no. 3 (1997): 11-21.

MacDonald, Martha, Shelley Phipps, and Lynn Lethbridge. "Taking its Toll: The Influence of Paid and Unpaid Work on Women's Well-Being." Feminist Economics 11, no. 1 (2005): 63-94.

Marx, Karl. Capital - Volume One: The Process of Production of Capital. Harmondsworth: Penguin, [1867] 1976.

—. Capital - Volume Two: The Process of Circulation of Capital. Harmondsworth: Penguin, [1885] 1978. . Capital - Volume Three: The Process of Capitalist Production as a Whole. Harmondsworth: Penguin, [1894] 1981.

Mayhew, Anne. "Culture: Core Concept Under Attack." Journal of Economic Issues 21, no. 2 (1987): 587. 615.

Miller, Edith. "Institutional Economics and Eternal Verities: A Contribution to the Discussion." In Institutionalist Method and Value: Essays in Honour of Paul Dale Bush, edited by Sasan Fayazmanesh, and Marc R. Tool. Cheltenham, UK and Northampton, MA: Edward Elgar Publishing, 1998.

Miller, Nigel James, and Christopher Tsoukis. "On the Optimality of Public Capital for Long-Run Economic Growth: Evidence from Panel Data.” Applied Economics 33, no. 3 (2001): 1117-1129.

Minsky, Hyman. Can "It" Happen Again? Essays on Instability and Finance. Armonk, NY: M.E. Sharpe, 1982.

Ofori-Dankwa, Joseph, and Scott D. Julian. "Complexifying Organizational Theory: Illustrations Using Time Research.” Academy of Management Review 26, no. 3 (2001): 415-430.

O'Hara, Phillip Anthony. "Methodological Principles of Institutional Political Economy: Holism, Evolution and Contradiction." Methodus 5, no. 1 (1993): 51-71.

—. "Veblen's Critique of Marx's Philosophical Preconceptions of Political Economy." European Journal of the History of Economic Thought 4, no. 1 (1997): 65-91.

-. Marx, Veblen and Contemporary Institutional Political Economy: Principles and Unstable Dynamics of Capitalism. Cheltenham, UK and Northampton, MA: Edward Elgar Publishing, 2000.

_- (ed). Encyclopedia of Political Economy. London and New York: Routledge. 2 vols. Paper edition, 2001.

—. "The Contemporary Relevance of Thorstein Veblen's Institutional-Evolutionary Political Economy." History of Economics Review 35 (2002): 78-103.

_ . "A New Family-Community Social Structure of Accumulation for the United States?" Forum for Social Economics 33, no. 2 (2004a): 51-80.

—. "The Wealth and Welfare of Nations, Continents and Corporations." In Global Political Economy and the Wealth of Nations: Performance, Institutions, Problems and Policies, edited by P.A. O'Hara. London and New York: Routledge, 2004b. 
- The Principle of Heterogeneous Agents: Class, Gender, Ethnicity and Species. GPERU Research Paper No. 2006/3, Global Political Economy Research Unit (GPERU), Curtin University, Perth, Australia, 2006 a.

—. Growth and Development in the Global Political Economy: Social Structures of Accumulation and Modes of Regulation. London and New York: Routledge, 2006b.

—_. "A Chinese Social Structure of Accumulation for Capitalist Long Wave Upswing?" Review of Radical Political Economics 38, no. 3 (2006c).

—. Principles of Institutional-Evolutionary Political Economy: Major Concepts and Applications to the Contemporary World. Forthcoming.

Peterson, Janice, and Margaret Lewis (eds.). The Elgar Companion to Feminist Economics. Cheltenham, UK and Northampton, MA: Edward Elgar Publishing, 1999.

Pini, Poalo. "Economic growth, technological change and employment: empirical evidence for a cumulative growth model with external causation for nine OECD countries: 1960-1990.” Structural Change and Economic Dynamics 6, no. 2 (1995): 185-213.

Polanyi, Karl. The Great Transformation: The Political and Economic Origins of Our Time. Boston: Beacon Press, [1944] 1957.

—_. "The Economy as Instituted Process." In Primitive, Archaic, and Modern Economies: Essays of Karl Polanyi, edited by George Dalton. Boston: Beacon Press, 1968.

Potts, Jason. The New Evolutionary Microeconomics. Cheltenham, UK and Northampton, MA: Edward Elgar Publishing, 2000.

Radzicki, Michael J. "Institutional Economics, Post Keynesian Economics, and System dynamics" Three Strands of a Heterodox Economics Braid." In The Future of Heterodox Economics, edited by John T. Harvey, and Robert F. Garnett. Ann Arbor: University of Michigan Press, 2006.

Radzicki, Michael J., and John D. Sterman. "Evolutionary Economics and System dynamics." In Evolutionary Concepts in Contemporary Economics, edited by Richard W. England. Ann Arbor: University of Michigan Press, 1994.

Resnick, Stephen, and Richard Wolff. "The Point and Purpose of Marx's Notion of Class." Rethinking Marxism 17, no. 1 (2005): 33-38.

RRPE. “The Review." Review of Radical Political Economics 37, no. 1 (2005): 123.

Reynolds, Peter. Political Economy: A Synthesis of Kaleckian and Post Keynesdian Economics. Sussex: Wheatsheaf Books, 1987.

Rochon, Louis-Philippe, and Matias Vernengo. Credit, Interest Rates and the Open Economy: Essays on Horizontalism. Cheltenham, UK and Northampton, MA: Edward Elgar Publishing, 2001.

Rodrigues, João. "Endogenous Preferences and Embeddedness: A Reappraisal of Karl Polanyi." Journal of Economic Issues 38, no. 1 (2004): 189-200.

Schumpeter, Joseph. The Theory of Economic Development, Oxford: Oxford University Press, [1911], 1938.

Sen, Amartya. Development as Freedom. New York: Anchor Books, 1999.

Sherman, Howard. "Institutions and the Business Cycle." Journal of Economic Issues 37, no. 3 (2003): 621 642.

Shughart, William F., and Laura Razzolini (eds.). The Elgar Companion to Public Choice. Cheltenham, UK and Northampton, MA: Edward Elgar Publishing, 2001.

Sinha, Ajit. "The Transformation Problem: Is the Standard Commodity a Solution?" Review of Radical Political Economics 32, no. 2 (2000): 265-281.

Stanfield, James Ronald, and Michael C. Carroll. "Governance and the Legitimacy of Corporate Power: A Path for Convergence of Heterodox Economics?" Journal of Economic Issue 38, no. 2 (2004): 363-370

Stanfield, James Ronald. The Economic Thought of Karl Polanyi: Lives and Livelihood. New York: St. Martin's Press, 1986.

- Economics, Power and Culture: Essays in the Development of Radical Institutionalism, New York: St. Martin's, 1995.

Sterman, John D. Business Dynamics: Systems Thinking and Modeling for a Complex World. London and New York: Irwin/McGraw-Hill, 2000.

Stilwell, Frank. Political Economy: The Contest of Economic Ideas. Oxford: Oxford University Press, 2002.

Stockhammer, Engelbert. "Financialisation and the Slowdown of Accumulation." Cambridge Journal of Economics 28, no. 5 (2004): 719-741. 
Tool, Marc. The Discretionary Economy: A Normative Theory of Political Economy, $3^{\text {rd }}$ edition. New Brunswick and London: Transactions Publishers, 2001.

Veblen, Thorstein. The Theory of the Leisure Class. London: Unwin, [1899] 1965.

Waller, William. "The Concept of Habit in Economic Analysis," Journal of Economic Issues 22, no. 1 (1982): 113-126.

Weber, Christian E. "Government Purchases, Government Transfers, and the Post-1970 Slowdown in U.S. Economic Growth.” Contemporary Economic Policy 18, no. 1 (2000): 107-123.

Whalen, Charles J. Political Economy for the 21 $1^{\text {st }}$ Century. Armonk, NY: M.E. Sharpe, 1996.

Wilber, Charles K., and Robert S. Harrison. "The Methodological Basis of Institutional Economics: Pattern Model, Storytelling, and Holism.” Journal of Economic Issues 12, no. 1 (1978): 61-89.

Wolfson, M.H. Financial Crises: Understanding the Postwar U.S. Experience, $2^{\text {nd }}$ edition. Armonk, New York and London: M.E. Sharpe, 1994.

Wray, Randall. Understanding Modern Money: The Key to Full Employment and Price Stability. Cheltenham, UK and Northampton, MA: Edward Elgar Publishing, 1998.

Yaghmaian, Behzad. "Globalization and the State: The Political Economy of Global Accumulation and Its Emerging Mode of Regulation." Science and Society 62, no. 2(1998): 241-265. 